\title{
A FUZZY LOGIC APPROACH FOR THE ESTIMATION OF PERFORMANCE HYDROXY DRY CELL WITH DIFFERENT PLATE COMBINATION
}

\author{
1Yusuf YILMAZ, ${ }^{2}$ Sadık ATA, ${ }^{3}$ Gürol ÖNAL, ${ }^{4}$ Abdullah IŞIKTAŞ, ${ }^{5}$ Kevser DINCER \\ ${ }^{1}$ Selçuk Üniversitesi, Mühendislik Fakültesi, Makine Mühendisliği Bölümü, Konya \\ ${ }^{2}$ KTO Karatay Üniversitesi, Mühendislik Fakültesi, Makine Mühendisliği Bölümü, Konya \\ ${ }^{3}$ Selçuk Üniversitesi, Mühendislik Fakültesi, Makine Mühendisliği Bölümü, Konya \\ ${ }^{4}$ Sinop Üniversitesi, Meslek Yüksekokulu, Makine ve Metal Teknolojileri Bölümü, Sinop \\ ${ }^{5}$ Selçuk Üniversitesi, Mühendislik Fakültesi, Makine Mühendisliği Bölümü, Konya \\ 1yyilmaz@selcuk.edu.tr, 2sadik.ata@karatay.edu.tr, 3gonal@selcuk.edu.tr, \\ ${ }^{4}$ aisiktas@sinop.edu.tr, ${ }^{5} \mathrm{kdincer@selcuk.edu.tr}$
}

(Geliş/Received: 10.10.2016; Kabul/Accepted in Revised Form: 20.06.2017 )

\begin{abstract}
In this study, hydroxy (HHO) dry cell with different plate combination performances in terms of current, temperature and flow rate were experimentally investigated and modeled with RuleBased Mamdani-Type Fuzzy (RBMTF) modeling technique. Input parameters plate number and time; output parameters current, temperature and flow rate were described by RBMTF if-the rules. The dimensions of the plates were $10 \times 10 \mathrm{~cm}^{2}$ and $11 \times 11 \mathrm{~cm}^{2}$. Current and temperature were measured for the different plate combination. This paper presents a fuzzy logic based study for estimating the uncertainty of the HHO drycell parameters. The 80 values between 90th and 270th seconds, which are not obtained from experimental work for $10 \times 10 \mathrm{~cm}^{2}$ and $11 \times 11 \mathrm{~cm}^{2}$ current, temperature and flow rate are predicted by fuzzy logic method. One of the results is; the current value predicted by RBMTF for the 11-2 plate combination and $t=90 \mathrm{~s}$ is less than the current value from the results of the experimental work for the 11-2 plate combination and $\mathrm{t}=60 \mathrm{~s}$, but higher than the current value from the results of the experimental work for 11-2 plate combination and $\mathrm{t}=120 \mathrm{~s}$. The comparison between experimental data and RBMTF is done by using three different statistical method. These are, root mean square error (RMSE), mean absolute error (MAE) and the coefficient of multiple determination $\left(\mathrm{R}^{2}\right)$. For $10 \times 10 \mathrm{~cm}^{2}$ dimension plate, RMSE, MAE and $\mathrm{R}^{2}$ for the current is $0.13,0.111$ and $96.44 \%$ respectively. For $11 \times 11 \mathrm{~cm}^{2}$ dimension plate, RMSE, MAE and $\mathrm{R}^{2}$ for the current is $0.07926,0.06466$ and $98.44 \%$ respectively. coefficient of multiple determinations $\left(\mathrm{R}^{2}\right)$. As a result, RBMTF model has shown satisfying relation with experimental results, which suggests an alternative approach to estimation of performance HHO dry cell with different plate combination.
\end{abstract}

Key Words: Fuzzy logic, HHO dry cell, Plate combination

\section{Farklı Plaka Kombinasyonlarında HHO Hücresinin Performansının Tahmin Edilmesinde Bulanık Mantık Yaklaşımı}

ÖZ: Bu çalışmada, hidroksi (HHO) hücresi farklı plaka kombinasyonlarında akım, sıcaklık ve debi yönünden deneysel olarak incelenmiş ve kural tabanlı Mamdani tipi bulanık mantık tekniği ile modellenmiştir. Bulanık mantık modelinde, giriş parametreleri plaka sayısı ve zaman; çıkış parametreleri akım, sıcaklık ve debi olarak tanımlanmıştır. Plaka boyutları $10 \times 10 \mathrm{~cm}^{2}$ ve $11 \times 11 \mathrm{~cm}^{2} \mathrm{~d} ı$. Farklı plaka kombinasyonlarında akım, sıcaklık ve debi ölçülmüştür. Bu çalışmada, deneysel çalışmada yapılmayan değerlerin bulanık mantık ile tahmin edilmesi işlenmiştir. $10 \times 10 \mathrm{~cm}^{2}$ ile $11 \times 11 \mathrm{~cm}^{2}$ plaka boyutlarında deneysel olarak yapılmayan 90 . ile 270. saniye arasında olan 80 değer, bulanık mantık ile tahmin ettirilmiştir. 11-2 plaka kombinasyonu ve $t=90$ s için bulanık mantık modeli ile tahmin edilen 
akım değeri, deneysel çalışmada 11-2 plaka kombinasyonu ve $\mathrm{t}=60$ s için belirlenen akım değerinden az; deneysel çalışmada 11-2 plaka kombinasyonu ve $\mathrm{t}=120$ s için belirlenen akım değerinden fazladır. Deneysel çalışma ve bulanık mantık ile elde edilen değerler üç farklı istatistik yöntemi kullanılarak karşılaştırılmıştır. Bu yöntemler; ortalama karesel hatanın karekökü (RMSE), ortalama mutlak hata (MAE) ve determinasyon katsayısı $\left(\mathrm{R}^{2}\right)^{\prime}$ dır. $10 \times 10 \mathrm{~cm}^{2}$ plaka boyutu için, RMSE, MAE ve $\mathrm{R}^{2}$ değerleri sırasiyla 0.13 , 0.111 ve \%96.44 olarak belirlenmiştir. $11 \times 11 \mathrm{~cm}^{2}$ plaka boyutu için, RMSE, MAE ve $\mathrm{R}^{2}$ değerleri sırasıyla 0.07926, 0.06466 ve \%98.44 olarak belirlenmiştir. Sonuç olarak, bulanık mantık ile elde edilen değerler, deneysel çalışmada tespit edilen değerler ile uyum göstermiştir. Bu çalışmada, farklı plaka boyutlarında HHO hücresinin performansının tahmin edilmesinde, bulanık mantık modelleme tekniğinin kullanılması önerilmektedir.

Anahtar Kelimeler: Bulanık mantık (BM), Hidroksi (HHO) hücresi, Plaka Kombinasyonu

\section{INTRODUCTION}

Fossil fuels currently constitute $82 \%$ of the global total primary energy sources and oil makes $31.5 \%$ of this. Of the global oil production, $62.2 \%$ is consumed by the transport sector. Thus, the automotive industry is the largest consumer of fossil oil. Studies have also shown that the demand for oil and gas is rising exponentially and indications are that fossil fuels will not outlast the century if current habits are not curtailed. Hence, in response to the growing fuel prices and the increasing pressures for a cleaner "greener" society, the automotive industry has made efforts to reduce emissions and increase fuel efficiency. These efforts have primarily focussed on emissions reductions using catalytic converters, reducing vehicle weight, using alternative structural materials, improving engine management and fuel supply systems, incorporating the stop - start technology and introducing alternative sources of energy such as hydrogen fuel cells, biofuels and others. Governments and municipalities have also made efforts through the development and implementation of legislation. As regulations become more restrictive and global fossil fuel prices increase, the search for more sustainable sources of transportation fuels becomes more urgent. The current research into alternative energy sources for motor vehicles is mainly concentrated around electric/battery powered cars, hydrogen fuel cells, solar and hydrogen powered cars. These technologies, as promising as they may be, will not completely replace the fossil fuelled internal combustion engine within the next few decades. One of the major hindrances will be the lack of supporting infrastructure such as fuel supply and distribution centres. There is therefore potential for a bridging or interim technology that can be incorporated into existing technology using the existing infrastructure, which can lead to greener use of available fossil resources. One such option is the introduction of hydrogen gas into the combustion process of an internal combustion engine (Madyira and Harding, 2014).

Hydrogen has a strong chance to take the place of conventional fossil fuils in traditional internal combustion engines. However, one of the main drawbacks hindering this chance is storage issues of hydrogen due to its extremely low density (about 14 times lower than water in storage conditions). There is also another issue of keeping hydrogen in storage place, due to its extremely high diffusivity. This issue requires higher insulation during carriage to prevent hydrogen diffuse through walls. Liquified hydrogen, despite having higher specific energy than petrol, is disadvantaged in terms of volumetric energetic storage about five times. Yet again its energy density is considerably higher than that of electric batteries, it is still a good candidate for fossil fuel replacement. Enhancing intake air of combustion process with hydrogen can improve flame speed, lean burn ability and flame quenching distance. However, production cost, along with the storage issues makes it a non-feasibile approach. Some of the pottential difficulties can be eliminated by usage of Brown's Gas or HHO (produced by electrolysis of water). What is more, usage of HHO surpasses reactivity of the natural hydrogen, improving engine emmissions, performance and fuel efficiency at expense of power in automotive 
electrical system or from generator designed for this purpose in automobile engine (Leelakrishnan et al., 2013).

$\mathrm{HHO}$ combustion in engine provides powerful and quick reaction and after release of energy $\mathrm{HHO}$ turns into a water vapor as emission. This results in higher torque in engine and easier cooling when compared to other fuels about 10 to 20 times. Considering a conventional combustion engine, temperature after combustion is about $250 \mathrm{~F}$ is inferior to the one enhanced with $\mathrm{HHO}$, which reaches $150 \mathrm{~F}$ to $200 \mathrm{~F}$ dueto vapor formation. By attaining lower temeperatures, engines can get a longer lifespan by lower temperature change during cycle and lower rate of oil degradation which is also improving oil changing period. This leads to another opportunity of cost saving in maintenance cost and longer service intervals (Chakrapani and Neelamegam, 2011).

$\mathrm{HHO}$ gas has an auto ignition temperature about $570^{\circ} \mathrm{C}\left(1065^{\circ} \mathrm{F}\right)$ and has a heating value of $241.8 \mathrm{~kJ}$ for a stoichiometric mixture at normal atmospheric pressure. HHO gas can ignite and convert to water vapor, releasing energy at concentration level of 4 to $94 \%$ hydrogen per volume. Flame temperature can vary despite heating value remains same. Flame temperature of $2800^{\circ} \mathrm{C}$ is attained when combustion occurs under stoichiometric ratio conditions, about $700^{\circ} \mathrm{C}$ hotter than a hydrogen flame in air (Sakthivel, 2014). This Energy's performance must be increased which is predicted to be more important in the future. One of the methods to determine the effects of the parameters on performance is fuzzy logic method.

In this study, two different plate combinations compared in terms of HHO dry cell performance and fuzzy logic modeling used to estimate of performance $\mathrm{HHO}$ dry cell at intermediate values. Unperformed experiments are predicted with RBMTF for current, temperature and flow rate values for every plate's 80 output between 90th and 270th seconds. Performance parameters are plate combination, time, current, temperature and flow rate. Study includes fuzzification of input variables, representation of fuzzy set with 9 linguistic variables, formation of rule basis and a comparison between output values obtained by experiments and by calculation based on generated rules and RBMTF technique. The comparison between experimental data and RBMTF is done by using three different statistical methods. These are, root mean square error (RMSE), mean absolute error (MAE) and the coefficient of multiple determination $\left(\mathrm{R}^{2}\right)$. Main objective of the study is to present that it is possible to estimate performance of HHO dry cell with a fuzzy logic approach.

\section{LITERATURE REVIEW}

In the existing literature, there have been many investigations on application of fuzzy logic. Some of briefly mentioned below. Keshwani et al. (Keshwani et al., 2008) carried out rule-based Mamdani-type fuzzy modeling of skin permeability. They proposed that potential uses of the presented models include rapid assessment of skin permeability of compounds to identify candidates for transdermal drug delivery and estimate toxicity risks. Shakhawat et al. (Shakhawat et al., 2006) studied fuzzy rule-based modelling for human health risk from naturally occurring radioactive materials in produced water. They concluded that a dual-barrier approach for human health risk assessment from naturally occurring radioactive materials in produced water. Yıldız et al. (Yıldız and Kişoğlu, 2011) examined with the size tables and body size numbers taken from ready-wear enterprises carrying out activities in the women's outside wear field, modelling a common body numbering system was aimed through the fuzzy logic system. They proposed that this modeling will reduce the problems related to consumer products by contributing in a positive sense to the marketing problems and to the competition in the garment industry. Özek et al. (Sinecen and Sinecen, 2004) studied modelling of air conditioning system by fuzzy logic approach, because one of the main problems in control systems is the difficulty to form the mathematical model associated with the control mechanism. They realized that the fuzzy logic without using mathematical model of control system can create control mechanism only with the help of linguistic variables. Tiryaki et al. (Tiryaki and Kazan, 2007) studied about dishwasher which is frequently used in daily life is modelled and simulated by using fuzzy logic. They concluded that if an 
appropriate hardware support and appropriate sensors are provided for the dishwasher, with the aim of the fuzzy logic model the washing process may be done without human intervention according to the inputs such as quantity of the dishes, type of the dishes by the machine. Işıktaş et al. (Işıktaş et al., 2016) studied about fuzzy logic modelling of performance HHO dry cell with different type membership functions. They noted that RBMTF which has a triangular membership function has a more better performance than other membership functions for determine performance of HHO dry cell. Ata and Dincer (Ata and Dincer, 2015; Ata and Dincer, 2015; Ata, 2015; Ata and Dincer, 2016 ) studied about rulebased Mamdani-type fuzzy (RBMTF) modeling of performance proton exchange membrane fuel cell with carbon nanotube. They noted that RBMTF can be successfully used for the specification PEM performances with coating carbon nanotube. Kim et al. (Kim and Kim, 1999) examined an electrical modelling of the fuel cell generation system. They used fuzzy logic controller to overcome inherent disadvantages such as uncontrollable large overshoot and large current ripple. They noted that fuzzy controller is very effective in output control and desired operating point operation, which in turn offers high system stability and performance. Tong et al. (Tong et al., 2013) studied about $1 \mathrm{~kW}$ PEM fuel cell unit and developed the models of stack voltage, cathode flow, anode flow. They proposed that the power demand of the external load can be provided by the fuel cell stack under the control of a real-time simplified variable universe fuzzy controller.

\section{MATERIALS AND METHODS}

\section{Experimental Study}

Figure 1 shows experimental system for this study. Water tank is used to store water the cells required. Thus the material of the tank needs to have the protection against corrosion. There are three outlets on the water tank. These are the gas inlet that the gas gets back to the tank, the gas outlet that the gas were taken, water outlet that water flows to the cell. Safety tank is an important element and is used to protect the main tank. This element contains water and prevent the flame to reach the main tank. Power supply is an element used to obtain HHO gas. Power supply needs to generate electricity. Stainless steel was chosen as the plate material and the thickness of the plate was $1 \mathrm{~mm}$. The dimensions of the plates were $10 \times 10 \mathrm{~cm}^{2}$. The plates has $10 \mathrm{~cm}$ length and $10 \mathrm{~cm}$ width. A piece that have the length of $2 \mathrm{~cm}$ was cut off from the corners of the plates. Thus, the power requirement reduced. End plates are selected from mica material. It is chosen to be observed during system operation. Gas inlet was drilled on top of the plates as water inlet was drilled on the bottom of the plates. The diameter of each hole is 8 $\mathrm{mm}$. Seals are selected from plastic. Each gasket has the diameter of $10 \mathrm{~cm}$ and the thickness of $2 \mathrm{~mm}$. The gaskets contact with the last plates are $4 \mathrm{~mm}$ thick. This is because the water inlet and the gas outlet is to ensure more comfortable and regular gas flow. Current, voltage and temperature were measured for the different plate combination. Tap water was used in the experiments and the system was set to 10 minutes. For each combinations, new cells were prepared. According to experimental work result, current values were increased with decreasing the number of plate. However, the current value did not exceed the highest value of 5.3 A. The reason of that, relation between the active surface area of the plates and the current drawn. It was observed that the highest ratio of the current value of the plate active surface area was $0.1 \mathrm{~A} / \mathrm{cm}^{2}$. The working temperature is an important parameter in this system and it varies according to the number of plates and current. The temperature was observed to be increased as the current drawn went up. The highest temperature value recorded during the experiments was $38{ }^{\circ} \mathrm{C}$. This value occured when the highest current value was $5.3 \mathrm{~A}$. The result of experimental work showed the voltage dropped as the number of plates reduced (Dincer et al., 2013). 


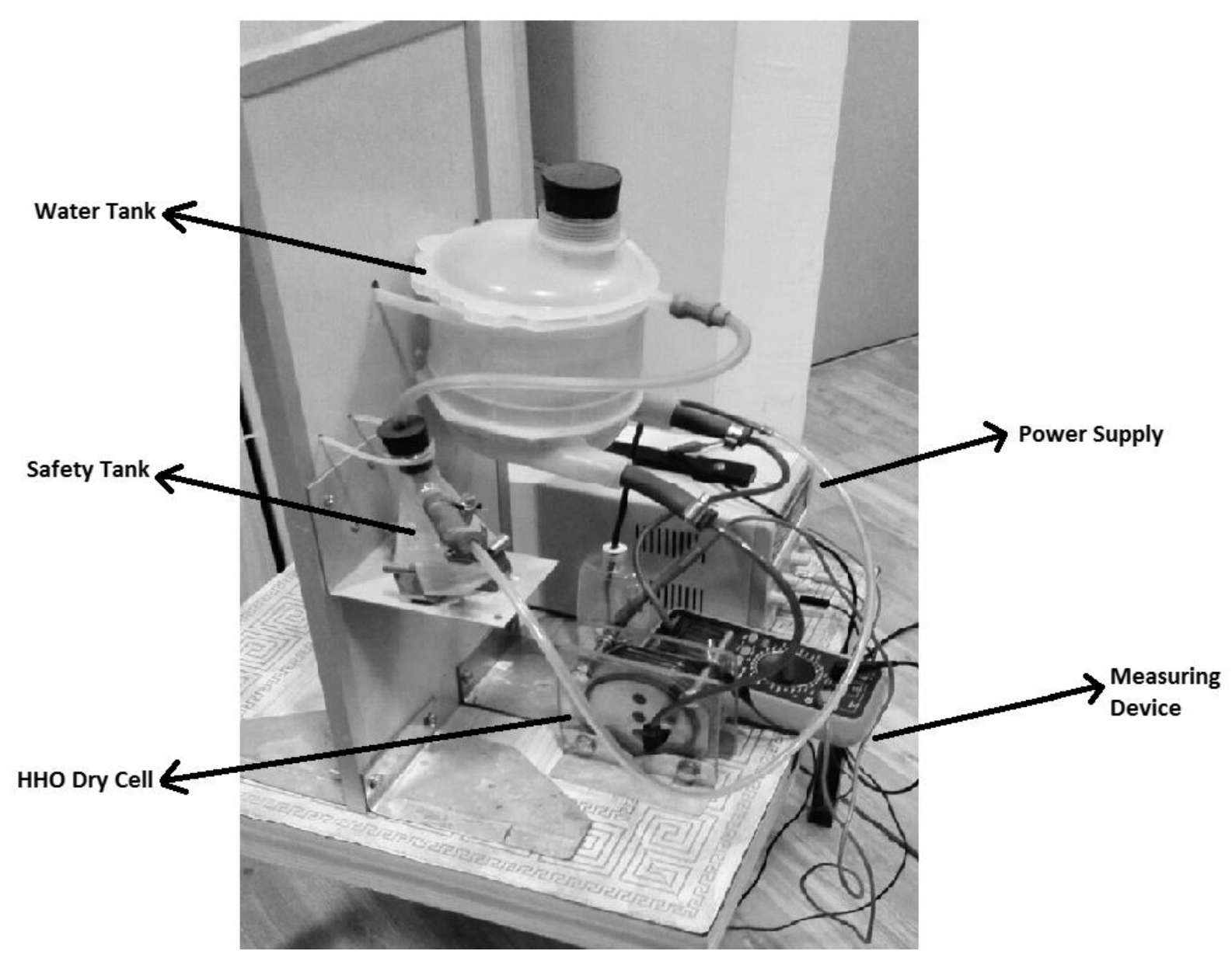

Figure 1. Experimental system

\section{Fuzzy Logic Modeling}

Mamdani-type fuzzy logic model is used to evaluate performance of HHO dry cell by this study. Mamdani's method is providing a relatively simple structure for 'min-max' operations, hence it is one of the most commonly used applications in numerous fields requiring specialized knowledge. Mamdani's method is a fuzzy logic method and can be applied in any kind of problem that has an input and output interconnected to each other. Method proposed by Ebrahim Mamdani in 1975 during an attempt to control a steam engine and boiler combination. Method foresees a synthesis of a set of linguistic control rules obtained from experienced human operators. Fuzzy Logic Toolbox explains Mamdani type inference as expectation of output membership functions as fuzzy sets. Mamdani-type fuzzy model is created in the following five steps:

a) Fuzzification of inputs in antecedent to a degree of membership between 0 and 1

b) Determining the weights of rules using fuzzy logic.

c) Application of AND and OR operations

d) Combining consequences to get an output distribution

e) Defuzzifying the output distribution (this step is used only if a crisp output is needed)

Advantages of the Mamdani Method as a summary; method is intuitive, well suited for usage of human input, has widespread acceptance (Bölgen, 2010). 


\section{RESULTS AND DISCUSSIONS}

HHO gas has substantial advantages when compared to the gasoline due to its high diffusivity. First two of these advantages is rate of formation of homogenous mixture is greater since HHO diffuses faster in mixture. Secondly, $\mathrm{HHO}$ can dilute quite fast under circumstances of leakage. Several researches show that 1866 litres of $\mathrm{HHO}$ gas is obtained from 1 liter of water, after ignition, the HHO gas returns to original volume after combustion (Sakthivel, 2014).

The aim of this study with the aid of experimental data, HHO dry cell performances in terms of current and temperature were modeled with fuzzy logic modeling technique. In the developed RBMTF system, output parameters $\mathrm{A}$ and $\mathrm{T}$ were determined using inlet parameters plate number and $\mathrm{t}$.

The following steps to design an fuzzy logic (FL) system:

1. Definition of the control objectives and criteria: What am I trying to control? What do I have to do to control the system? What kind of response do I need? What are the possible (probable) system failure modes?

2. Determination of the input and output relationships. One should choose a minimum number of variables for input to the FL engine (typically error and rate-of-change-of-error).

3. Break the control problem down into FL rules. The problem should be split into a series of IF $X$ AND Y THEN $Z$ rules that define the desired system output response for given system input conditions.

4. Creation of FL membership functions. The memberships defines the meaning (values) of Input/Output terms used in the rules.

5. System test: evaluate the results, tune the rules and membership functions, and retest until satisfactory results are obtained (Esteves, 2009).

In this study, hydroxy cell performances were modeled with a RBMTF modeling technique. Input parameters plate number and time; output parameters current, temperature and flow rate were described by RBMTF if-the rules (Fig. 2). Numerical parameters of input and output variables were fuzzificated as linguistic variables: Very Very Low $\left(\mathrm{L}_{1}\right)$, Very Low $\left(\mathrm{L}_{2}\right)$, Low $\left(\mathrm{L}_{3}\right)$, Negative Medium $\left(\mathrm{L}_{4}\right)$, Medium (L5), Positive Medium (L6), High (L7), Very High (L8) and Very Very High (L9) linguistic classes (Tables 1 and 2). The 80 values between 90th and 270th seconds, which are not obtained from experimental work for $10 \times 10 \mathrm{~cm}^{2}$ and $11 \times 11 \mathrm{~cm}^{2}$ current, temperature and flow rate are predicted by fuzzy logic method. Fig. 3 and Fig. 4 shows respectively, the comparison of experimental data for 10x10 $\mathrm{cm}^{2}$ and $11 \times 11 \mathrm{~cm}^{2}$ plate dimensions with fuzzy prediction for the variation of time with plate combination of current, temperature and flow rate values. From a comparison of the experimental results with the results of the fuzzy logic study, one can see that the results are quite compatible.

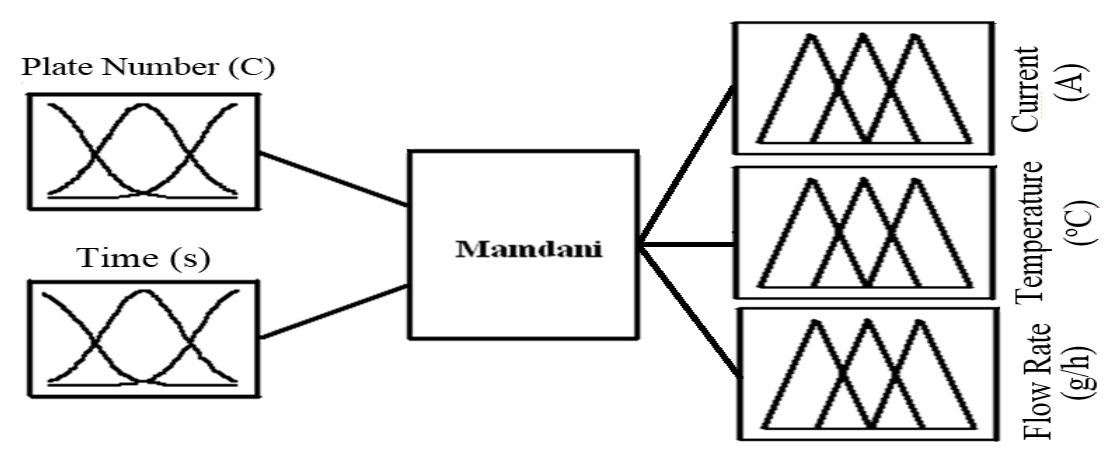

Figure 2. Designed fuzzy modeling structure the performance of hydroxy cell performances 
Table 1. Fuzzy sets of input variables : Plate Number (C) and Time (s)

\begin{tabular}{|c|cccccccccc|}
\hline $\begin{array}{c}\text { Membership } \\
\text { name }\end{array}$ & $\begin{array}{c}\text { very } \\
\text { very } \\
\text { low }\end{array}$ & very low & low & $\begin{array}{c}\text { negative } \\
\text { medium }\end{array}$ & medium & $\begin{array}{c}\text { positive } \\
\text { medium }\end{array}$ & high & $\begin{array}{c}\text { very } \\
\text { high }\end{array}$ & $\begin{array}{c}\text { very } \\
\text { very } \\
\text { high }\end{array}$ \\
\hline & $\mathrm{L}_{1}$ & $\mathrm{~L}_{2}$ & $\mathrm{~L}_{3}$ & $\mathrm{~L}_{4}$ & $\mathrm{~L}_{5}$ & $\mathrm{~L}_{6}$ & $\mathrm{~L}_{7}$ & $\mathrm{~L}_{8}$ & $\mathrm{~L}_{9}$ \\
Plate Number & $\mathrm{C}_{1}$ & $\mathrm{C}_{2}$ & $\mathrm{C}_{3}$ & $\mathrm{C}_{4}$ & $\mathrm{C}_{5}$ & $\mathrm{C}_{6}$ & $\mathrm{C}_{7}$ & $\mathrm{C}_{8}$ & $\mathrm{C}_{9}$ \\
Time (s) & $\mathrm{t}_{1}$ & $\mathrm{t}_{2}$ & $\mathrm{t}_{3}$ & $\mathrm{t}_{4}$ & $\mathrm{t}_{5}$ & $\mathrm{t}_{6}$ & $\mathrm{t}_{7}$ & $\mathrm{t}_{8}$ & $\mathrm{t}_{9}$ \\
\hline
\end{tabular}

Table 2. Fuzzy sets of output variables: (a) Current (A), (b) Temperature $\left({ }^{\circ} \mathrm{C}\right)$, (c) Flow Rate (g/h)

\begin{tabular}{|c|cccccccccc|}
\hline $\begin{array}{c}\text { Membership } \\
\text { name }\end{array}$ & $\begin{array}{c}\text { very } \\
\text { very } \\
\text { low }\end{array}$ & $\begin{array}{c}\text { very } \\
\text { low }\end{array}$ & low & $\begin{array}{c}\text { negative } \\
\text { medium }\end{array}$ & medium & $\begin{array}{c}\text { positive } \\
\text { medium }\end{array}$ & high & $\begin{array}{c}\text { very } \\
\text { high }\end{array}$ & $\begin{array}{c}\text { very } \\
\text { very } \\
\text { high }\end{array}$ \\
\hline & $\mathrm{L}_{1}$ & $\mathrm{~L}_{2}$ & $\mathrm{~L}_{3}$ & $\mathrm{~L}_{4}$ & $\mathrm{~L} 5$ & $\mathrm{~L} 6$ & $\mathrm{~L} 7$ & $\mathrm{~L} 8$ & $\mathrm{~L} 9$ \\
Current (A) & $\mathrm{A}_{1}$ & $\mathrm{~A}_{2}$ & $\mathrm{~A}_{3}$ & $\mathrm{~A}_{4}$ & $\mathrm{~A}_{5}$ & $\mathrm{~A}_{6}$ & $\mathrm{~A} 7$ & $\mathrm{~A} 8$ & $\mathrm{~A} 9$ \\
\hline
\end{tabular}

b

\begin{tabular}{|c|cccccccccc|}
\hline $\begin{array}{c}\text { Membership } \\
\text { name }\end{array}$ & $\begin{array}{c}\text { very } \\
\text { very } \\
\text { low }\end{array}$ & $\begin{array}{c}\text { very } \\
\text { low }\end{array}$ & low & $\begin{array}{c}\text { negative } \\
\text { medium }\end{array}$ & medium & $\begin{array}{c}\text { positive } \\
\text { medium }\end{array}$ & high & $\begin{array}{c}\text { very } \\
\text { high }\end{array}$ & $\begin{array}{c}\text { very } \\
\text { very } \\
\text { high }\end{array}$ \\
\hline & $\mathrm{L}_{1}$ & $\mathrm{~L}_{2}$ & $\mathrm{~L}_{3}$ & $\mathrm{~L}_{4}$ & $\mathrm{~L}_{5}$ & $\mathrm{~L}_{6}$ & $\mathrm{~L}_{7}$ & $\mathrm{~L}_{8}$ & $\mathrm{~L} 9$ \\
Temperature $\left({ }^{\circ} \mathrm{C}\right)$ & $\mathrm{T}_{1}$ & $\mathrm{~T}_{2}$ & $\mathrm{~T}_{3}$ & $\mathrm{~T}_{4}$ & $\mathrm{~T}_{5}$ & $\mathrm{~T}_{6}$ & $\mathrm{~T}_{7}$ & $\mathrm{~T}_{8}$ & $\mathrm{~T}_{9}$ \\
\hline
\end{tabular}

c

\begin{tabular}{|c|c|c|c|c|c|c|c|c|c|}
\hline $\begin{array}{c}\text { Membership } \\
\text { name }\end{array}$ & $\begin{array}{l}\text { very } \\
\text { very } \\
\text { low }\end{array}$ & $\begin{array}{l}\text { very } \\
\text { low }\end{array}$ & low & $\begin{array}{l}\text { negative } \\
\text { medium }\end{array}$ & medium & $\begin{array}{l}\text { positive } \\
\text { medium }\end{array}$ & high & $\begin{array}{l}\text { very } \\
\text { high }\end{array}$ & $\begin{array}{l}\text { very } \\
\text { very } \\
\text { high }\end{array}$ \\
\hline & $\mathrm{L}_{1}$ & $\mathrm{~L}_{2}$ & $\mathrm{~L}_{3}$ & $\mathrm{~L}_{4}$ & $\mathrm{~L}_{5}$ & L6 & $\mathrm{L}_{7}$ & L8 & L9 \\
\hline Flow Rate (g/h) & $\mathrm{FR}_{1}$ & $\mathrm{FR}_{2}$ & $\mathrm{FR}_{3}$ & $\mathrm{FR}_{4}$ & $\mathrm{FR}_{5}$ & $\mathrm{FR}_{6}$ & $\mathrm{FR}_{7}$ & FR8 & $\mathrm{FR}_{9}$ \\
\hline
\end{tabular}

The most important factor that affects the performance of the fuzzy logic system is the number of the rules and their accuracy. In this study, there are 2 inputs and 81 rules for the every output of 9x9 matrix and totally $81 \times 3=243$ rules are generated. Rules of RBMTF for FR, A, T was given in Tables 3-5, respectively. 
Table 3. Rules of RBMTF for current (A)

\begin{tabular}{|c|c|c|c|c|c|c|c|c|c|c|c|c|c|}
\hline $\begin{array}{c}\text { Rule } \\
\text { number }\end{array}$ & & $\mathrm{C}$ & & $\mathbf{t}$ & & A & $\begin{array}{c}\text { Rule } \\
\text { number }\end{array}$ & & $\mathrm{C}$ & & $\mathbf{t}$ & & A \\
\hline 1 & If & $\mathrm{C}$ is $\mathrm{C}_{1}$ & and & $\mathrm{t}$ is $\mathrm{t}_{1}$ & then & $\mathrm{A}$ is $\mathrm{A} 9$ & 42 & If & $\mathrm{C}$ is $\mathrm{C}_{5}$ & and & $\mathrm{t}_{\text {is }} \mathrm{t}_{6}$ & then & $\mathrm{A}$ is $\mathrm{A} 9$ \\
\hline 2 & If & $\mathrm{C}$ is $\mathrm{C}_{1}$ & and & $\mathrm{t}$ is $\mathrm{t}_{2}$ & then & $\mathrm{A}$ is $\mathrm{A} 9$ & 43 & If & $\mathrm{C}$ is $\mathrm{C}_{5}$ & and & $\mathrm{t}$ is $\mathrm{t} 7$ & then & $\mathrm{A}$ is $\mathrm{A} 9$ \\
\hline 3 & If & $\mathrm{C}$ is $\mathrm{C}_{1}$ & and & $\mathrm{t}$ is $\mathrm{t}_{3}$ & then & $\mathrm{A}$ is $\mathrm{A} 9$ & 44 & If & $\mathrm{C}$ is $\mathrm{C}_{5}$ & and & $\mathrm{t}$ is $\mathrm{t}_{8}$ & then & $\mathrm{A}$ is $\mathrm{A} 9$ \\
\hline 4 & If & $\mathrm{C}$ is $\mathrm{C}_{1}$ & and & $\mathrm{t}$ is $\mathrm{t}_{4}$ & then & $\mathrm{A}$ is $\mathrm{A} 9$ & 45 & If & $\mathrm{C}$ is $\mathrm{C}_{5}$ & and & $\mathrm{t}$ is $\mathrm{t}_{9}$ & then & $\mathrm{A}$ is $\mathrm{A} 9$ \\
\hline 5 & If & $\mathrm{C}$ is $\mathrm{C}_{1}$ & and & $\mathrm{t}$ is $\mathrm{t}_{5}$ & then & $\mathrm{A}$ is $\mathrm{A} 9$ & 46 & If & $\mathrm{C}$ is $\mathrm{C}_{6}$ & and & $\mathrm{t}$ is $\mathrm{t}_{1}$ & then & $\mathrm{A}$ is $\mathrm{A}_{3}$ \\
\hline 6 & If & $\mathrm{C}$ is $\mathrm{C}_{1}$ & and & $\mathrm{t}$ is $\mathrm{t}_{6}$ & then & $\mathrm{A}$ is $\mathrm{A} 9$ & 47 & If & $\mathrm{C}$ is $\mathrm{C}_{6}$ & and & $\mathrm{t}$ is $\mathrm{t}_{2}$ & then & $\mathrm{A}$ is $\mathrm{A}_{3}$ \\
\hline 7 & If & $\mathrm{C}$ is $\mathrm{C}_{1}$ & and & $\mathrm{t}$ is $\mathrm{t} 7$ & then & $\mathrm{A}$ is $\mathrm{A} 9$ & 48 & If & $\mathrm{C}$ is $\mathrm{C}_{6}$ & and & $\mathrm{t}_{\text {is }} \mathrm{t}_{3}$ & then & $\mathrm{A}$ is $\mathrm{A}_{4}$ \\
\hline 8 & If & $\mathrm{C}$ is $\mathrm{C}_{1}$ & and & $\mathrm{t}$ is $\mathrm{t}_{8}$ & then & $\mathrm{A}$ is $\mathrm{A} 9$ & 49 & If & $\mathrm{C}$ is $\mathrm{C}_{6}$ & and & $\mathrm{t}$ is $\mathrm{t}_{4}$ & then & $\mathrm{A}$ is $\mathrm{A}_{4}$ \\
\hline 9 & If & $\mathrm{C}$ is $\mathrm{C}_{1}$ & and & $\mathrm{t}$ is $\mathrm{t}_{9}$ & then & $\mathrm{A}$ is $\mathrm{A} 9$ & 50 & If & $\mathrm{C}$ is $\mathrm{C}_{6}$ & and & $\mathrm{t}$ is $\mathrm{t}_{5}$ & then & $\mathrm{A}$ is $\mathrm{A}_{4}$ \\
\hline 10 & If & $\mathrm{C}$ is $\mathrm{C}_{2}$ & and & $\mathrm{t}$ is $\mathrm{t}_{1}$ & then & $\mathrm{A}$ is $\mathrm{A} 9$ & 51 & If & $\mathrm{C}$ is $\mathrm{C}_{6}$ & and & $\mathrm{t}_{\text {is }} \mathrm{t}_{6}$ & then & $\mathrm{A}$ is $\mathrm{A}_{5}$ \\
\hline 11 & If & $\mathrm{C}$ is $\mathrm{C}_{2}$ & and & $\mathrm{t}$ is $\mathrm{t}_{2}$ & then & $\mathrm{A}$ is $\mathrm{A} 9$ & 52 & If & $\mathrm{C}$ is $\mathrm{C}_{6}$ & and & $\mathrm{t}$ is $\mathrm{t}_{7}$ & then & $\mathrm{A}$ is $\mathrm{A}_{5}$ \\
\hline 12 & If & $\mathrm{C}$ is $\mathrm{C}_{2}$ & and & $\mathrm{t}$ is $\mathrm{t}_{3}$ & then & $\mathrm{A}$ is $\mathrm{A} 9$ & 53 & If & $\mathrm{C}$ is $\mathrm{C}_{6}$ & and & $\mathrm{t}$ is $\mathrm{t}_{8}$ & then & $\mathrm{A}$ is $\mathrm{A}_{5}$ \\
\hline 13 & If & $\mathrm{C}$ is $\mathrm{C}_{2}$ & and & $\mathrm{t}$ is $\mathrm{t}_{4}$ & then & $\mathrm{A}$ is $\mathrm{A} 9$ & 54 & If & $\mathrm{C}$ is $\mathrm{C}_{6}$ & and & $\mathrm{t}$ is $\mathrm{t}_{9}$ & then & $\mathrm{A}$ is $\mathrm{A}_{5}$ \\
\hline 14 & If & $\mathrm{C}$ is $\mathrm{C}_{2}$ & and & $\mathrm{t}$ is $\mathrm{t}_{5}$ & then & $\mathrm{A}$ is $\mathrm{A} 9$ & 55 & If & $\mathrm{C}$ is $\mathrm{C}_{7}$ & and & $\mathrm{t}$ is $\mathrm{t}_{1}$ & then & $\mathrm{A}$ is $\mathrm{A}_{1}$ \\
\hline 15 & If & $\mathrm{C}$ is $\mathrm{C}_{2}$ & and & $\mathrm{t}_{\text {is }} \mathrm{t}_{6}$ & then & $\mathrm{A}$ is $\mathrm{A} 9$ & 56 & If & $\mathrm{C}$ is $\mathrm{C}_{7}$ & and & $\mathrm{t}$ is $\mathrm{t}_{2}$ & then & $\mathrm{A}$ is $\mathrm{A}_{1}$ \\
\hline 16 & If & $\mathrm{C}$ is $\mathrm{C}_{2}$ & and & $\mathrm{t}$ is $\mathrm{t}_{7}$ & then & $\mathrm{A}$ is $\mathrm{A} 9$ & 57 & If & $\mathrm{C}$ is $\mathrm{C}_{7}$ & and & $\mathrm{t}_{\text {is }} \mathrm{t}_{3}$ & then & $\mathrm{A}$ is $\mathrm{A}_{1}$ \\
\hline 17 & If & $\mathrm{C}$ is $\mathrm{C}_{2}$ & and & $\mathrm{t}$ is $\mathrm{t}_{8}$ & then & $\mathrm{A}$ is $\mathrm{A} 9$ & 58 & If & $\mathrm{C}$ is $\mathrm{C}_{7}$ & and & $\mathrm{t}$ is $\mathrm{t}_{4}$ & then & $\mathrm{A}$ is $\mathrm{A}_{2}$ \\
\hline 18 & If & $\mathrm{C}$ is $\mathrm{C}_{2}$ & and & $\mathrm{t}$ is $\mathrm{t}_{9}$ & then & $\mathrm{A}$ is $\mathrm{A} 9$ & 59 & If & $\mathrm{C}$ is $\mathrm{C}_{7}$ & and & $\mathrm{t}$ is $\mathrm{t}_{5}$ & then & $\mathrm{A}$ is $\mathrm{A}_{2}$ \\
\hline 19 & If & $\mathrm{C}$ is $\mathrm{C}_{3}$ & and & $\mathrm{t}$ is $\mathrm{t}_{1}$ & then & $\mathrm{A}$ is $\mathrm{A}_{9}$ & 60 & If & $\mathrm{C}$ is $\mathrm{C}_{7}$ & and & $t_{\text {is }} t_{6}$ & then & $\mathrm{A}$ is $\mathrm{A}_{2}$ \\
\hline 20 & If & $\mathrm{C}$ is $\mathrm{C}_{3}$ & and & $\mathrm{t}$ is $\mathrm{t}_{2}$ & then & $\mathrm{A}$ is $\mathrm{A}_{9}$ & 61 & If & $\mathrm{C}$ is $\mathrm{C}_{7}$ & and & $\mathrm{t}$ is $\mathrm{t}_{7}$ & then & $\mathrm{A}$ is $\mathrm{A}_{2}$ \\
\hline 21 & If & $\mathrm{C}$ is $\mathrm{C}_{3}$ & and & $\mathrm{t}_{\text {is }} \mathrm{t}_{3}$ & then & $\mathrm{A}$ is $\mathrm{A} 9$ & 62 & If & $\mathrm{C}$ is $\mathrm{C}_{7}$ & and & $\mathrm{t}$ is $\mathrm{t}_{8}$ & then & $\mathrm{A}$ is $\mathrm{A}_{2}$ \\
\hline 22 & If & $\mathrm{C}$ is $\mathrm{C}_{3}$ & and & $\mathrm{t}$ is $\mathrm{t}_{4}$ & then & $\mathrm{A}$ is $\mathrm{A} 9$ & 63 & If & $\mathrm{C}$ is $\mathrm{C}_{7}$ & and & $\mathrm{t}$ is $\mathrm{t}_{9}$ & then & $\mathrm{A}$ is $\mathrm{A}_{2}$ \\
\hline 23 & If & $\mathrm{C}$ is $\mathrm{C}_{3}$ & and & $\mathrm{t}$ is $\mathrm{t}_{5}$ & then & $\mathrm{A}$ is $\mathrm{A} 9$ & 64 & If & $\mathrm{C}$ is $\mathrm{C}_{8}$ & and & $\mathrm{t}$ is $\mathrm{t}_{1}$ & then & $\mathrm{A}$ is $\mathrm{A}_{1}$ \\
\hline 24 & If & $\mathrm{C}$ is $\mathrm{C}_{3}$ & and & $\mathrm{t}_{\text {is }} \mathrm{t}_{6}$ & then & $\mathrm{A}$ is $\mathrm{A}_{9}$ & 65 & If & $\mathrm{C}$ is $\mathrm{C}_{8}$ & and & $\mathrm{t}$ is $\mathrm{t}_{2}$ & then & $\mathrm{A}$ is $\mathrm{A}_{1}$ \\
\hline 25 & If & $\mathrm{C}$ is $\mathrm{C}_{3}$ & and & $\mathrm{t}$ is $\mathrm{t} 7$ & then & $\mathrm{A}$ is $\mathrm{A} 9$ & 66 & If & $\mathrm{C}$ is $\mathrm{C}_{8}$ & and & $\mathrm{t}_{\text {is }} \mathrm{t}_{3}$ & then & $\mathrm{A}$ is $\mathrm{A}_{1}$ \\
\hline 26 & If & $\mathrm{C}$ is $\mathrm{C}_{3}$ & and & $\mathrm{t}$ is $\mathrm{t} 8$ & then & $\mathrm{A}$ is $\mathrm{A}_{9}$ & 67 & If & $\mathrm{C}$ is $\mathrm{C}_{8}$ & and & $\mathrm{t}$ is $\mathrm{t}_{4}$ & then & $\mathrm{A}$ is $\mathrm{A}_{1}$ \\
\hline 27 & If & $\mathrm{C}$ is $\mathrm{C}_{3}$ & and & $\mathrm{t}$ is $\mathrm{t}_{9}$ & then & $\mathrm{A}$ is $\mathrm{A} 9$ & 68 & If & $\mathrm{C}$ is $\mathrm{C}_{8}$ & and & $\mathrm{t}$ is $\mathrm{t}_{5}$ & then & $\mathrm{A}$ is $\mathrm{A}_{1}$ \\
\hline 28 & If & $\mathrm{C}$ is $\mathrm{C}_{4}$ & and & $\mathrm{t}$ is $\mathrm{t}_{1}$ & then & $\mathrm{A}$ is $\mathrm{A} 8$ & 69 & If & $\mathrm{C}$ is $\mathrm{C}_{8}$ & and & $\mathrm{t}_{\text {is }} \mathrm{t}_{6}$ & then & $\mathrm{A}$ is $\mathrm{A}_{1}$ \\
\hline 29 & If & $\mathrm{C}$ is $\mathrm{C}_{4}$ & and & $\mathrm{t}$ is $\mathrm{t}_{2}$ & then & $\mathrm{A}$ is $\mathrm{A} 9$ & 70 & If & $\mathrm{C}$ is $\mathrm{C}_{8}$ & and & $\mathrm{t}$ is $\mathrm{t}_{7}$ & then & $\mathrm{A}$ is $\mathrm{A}_{1}$ \\
\hline 30 & If & $\mathrm{C}$ is $\mathrm{C}_{4}$ & and & $\mathrm{t}$ is $\mathrm{t}_{3}$ & then & $\mathrm{A}$ is $\mathrm{A} 9$ & 71 & If & $\mathrm{C}$ is $\mathrm{C}_{8}$ & and & $\mathrm{t}$ is $\mathrm{t} 8$ & then & $\mathrm{A}$ is $\mathrm{A}_{2}$ \\
\hline 31 & If & $\mathrm{C}$ is $\mathrm{C}_{4}$ & and & $\mathrm{t}$ is $\mathrm{t}_{4}$ & then & $\mathrm{A}$ is $\mathrm{A}_{9}$ & 72 & If & $\mathrm{C}$ is $\mathrm{C}_{8}$ & and & $\mathrm{t}$ is $\mathrm{t}_{9}$ & then & $\mathrm{A}$ is $\mathrm{A}_{2}$ \\
\hline 32 & If & $\mathrm{C}$ is $\mathrm{C}_{4}$ & and & $\mathrm{t}$ is $\mathrm{t}_{5}$ & then & $\mathrm{A}$ is $\mathrm{A} 9$ & 73 & If & $\mathrm{C}$ is $\mathrm{C}_{9}$ & and & $\mathrm{t}$ is $\mathrm{t}_{1}$ & then & $\mathrm{A}$ is $\mathrm{A}_{1}$ \\
\hline 33 & If & $\mathrm{C}$ is $\mathrm{C}_{4}$ & and & $\mathrm{t}_{\text {is }} \mathrm{t}_{6}$ & then & $\mathrm{A}$ is $\mathrm{A} 9$ & 74 & If & $\mathrm{C}$ is $\mathrm{C}_{9}$ & and & $\mathrm{t}$ is $\mathrm{t}_{2}$ & then & $\mathrm{A}$ is $\mathrm{A}_{1}$ \\
\hline 34 & If & $\mathrm{C}$ is $\mathrm{C}_{4}$ & and & $\mathrm{t}$ is $\mathrm{t} 7$ & then & $\mathrm{A}$ is $\mathrm{A} 9$ & 75 & If & $\mathrm{C}$ is $\mathrm{C}_{9}$ & and & $\mathrm{t}_{\text {is }} \mathrm{t}_{3}$ & then & $\mathrm{A}$ is $\mathrm{A}_{1}$ \\
\hline 35 & If & $\mathrm{C}$ is $\mathrm{C}_{4}$ & and & $\mathrm{t}$ is $\mathrm{t}_{8}$ & then & $\mathrm{A}$ is $\mathrm{A}_{9}$ & 76 & If & $\mathrm{C}$ is $\mathrm{C}_{9}$ & and & $\mathrm{t}$ is $\mathrm{t}_{4}$ & then & $\mathrm{A}$ is $\mathrm{A}_{1}$ \\
\hline 36 & If & $\mathrm{C}$ is $\mathrm{C}_{4}$ & and & $\mathrm{t}$ is $\mathrm{t}_{9}$ & then & $\mathrm{A}$ is $\mathrm{A} 9$ & 77 & If & $\mathrm{C}$ is $\mathrm{C}_{9}$ & and & $\mathrm{t}$ is $\mathrm{t}_{5}$ & then & $\mathrm{A}$ is $\mathrm{A}_{1}$ \\
\hline 37 & If & $\mathrm{C}$ is $\mathrm{C}_{5}$ & and & $\mathrm{t}$ is $\mathrm{t}_{1}$ & then & $\mathrm{A}$ is $\mathrm{A}_{4}$ & 78 & If & $\mathrm{C}$ is $\mathrm{C}_{9}$ & and & $\mathrm{t}_{\text {is }} \mathrm{t}_{6}$ & then & $\mathrm{A}$ is $\mathrm{A}_{1}$ \\
\hline 38 & If & $\mathrm{C}$ is $\mathrm{C}_{5}$ & and & $\mathrm{t}$ is $\mathrm{t}_{2}$ & then & $\mathrm{A}$ is $\mathrm{A}_{5}$ & 79 & If & $\mathrm{C}$ is $\mathrm{C}_{9}$ & and & $\mathrm{t}$ is $\mathrm{t} 7$ & then & $\mathrm{A}$ is $\mathrm{A}_{1}$ \\
\hline 39 & If & $\mathrm{C}$ is $\mathrm{C}_{5}$ & and & $\mathrm{t}$ is $\mathrm{t} 3$ & then & $\mathrm{A}$ is $\mathrm{A} 7$ & 80 & If & $\mathrm{C}$ is $\mathrm{C}_{9}$ & and & $\mathrm{t}$ is $\mathrm{t} 8$ & then & $\mathrm{A}$ is $\mathrm{A}_{1}$ \\
\hline 40 & If & $\mathrm{C}$ is $\mathrm{C}_{5}$ & and & $\mathrm{t}$ is $\mathrm{t}_{4}$ & then & $\mathrm{A}$ is $\mathrm{A}_{8}$ & 81 & If & $\mathrm{C}$ is $\mathrm{C}_{9}$ & and & $\mathrm{t}$ is $\mathrm{t} 9$ & then & $\mathrm{A}$ is $\mathrm{A}_{1}$ \\
\hline 41 & If & $\mathrm{C}$ is $\mathrm{C}_{5}$ & and & $\mathrm{t}$ is $\mathrm{t}_{5}$ & then & $\mathrm{A}$ is $\mathrm{A} 9$ & & & & & & & \\
\hline
\end{tabular}


Table 4. Rules of RBMTF for temperature $\left({ }^{\circ} \mathrm{C}\right)$

\begin{tabular}{|c|c|c|c|c|c|c|c|c|c|c|c|c|c|}
\hline $\begin{array}{c}\text { Rule } \\
\text { number }\end{array}$ & & C & & $\mathbf{t}$ & & $\mathrm{T}$ & $\begin{array}{c}\text { Rule } \\
\text { number }\end{array}$ & & C & & $\mathbf{t}$ & & $\mathrm{T}$ \\
\hline 1 & If & $\mathrm{C}$ is $\mathrm{C}_{1}$ & and & $\mathrm{t}$ is $\mathrm{t}_{1}$ & then & $\mathrm{T}$ is $\mathrm{T}_{2}$ & 42 & If & $\mathrm{C}$ is $\mathrm{C}_{5}$ & and & $t_{\text {is }} t_{6}$ & then & $\mathrm{T}$ is $\mathrm{T}_{7}$ \\
\hline 2 & If & $\mathrm{C}$ is $\mathrm{C}_{1}$ & and & $\mathrm{t}$ is $\mathrm{t}_{2}$ & then & $\mathrm{T}$ is $\mathrm{T}_{3}$ & 43 & If & $\mathrm{C}$ is $\mathrm{C}_{5}$ & and & $\mathrm{t}$ is $\mathrm{t}_{7}$ & then & $\mathrm{T}$ is $\mathrm{T}_{8}$ \\
\hline 3 & If & $\mathrm{C}$ is $\mathrm{C}_{1}$ & and & $\mathrm{t}$ is $\mathrm{t}_{3}$ & then & $\mathrm{T}$ is $\mathrm{T}_{3}$ & 44 & If & $\mathrm{C}$ is $\mathrm{C}_{5}$ & and & $\mathrm{t}$ is $\mathrm{t} 8$ & then & $\mathrm{T}$ is $\mathrm{T}_{9}$ \\
\hline 4 & If & $\mathrm{C}$ is $\mathrm{C}_{1}$ & and & $\mathrm{t}$ is $\mathrm{t}_{4}$ & then & $\mathrm{T}$ is $\mathrm{T}_{3}$ & 45 & If & $\mathrm{C}$ is $\mathrm{C}_{5}$ & and & $\mathrm{t}$ is $\mathrm{t9}$ & then & $\mathrm{T}$ is $\mathrm{T}_{9}$ \\
\hline 5 & If & $\mathrm{C}$ is $\mathrm{C}_{1}$ & and & $\mathrm{t}$ is $\mathrm{t}_{5}$ & then & $\mathrm{T}$ is $\mathrm{T}_{3}$ & 46 & If & $\mathrm{C}$ is $\mathrm{C}_{6}$ & and & $t$ is $t_{1}$ & then & $\mathrm{T}$ is $\mathrm{T}_{2}$ \\
\hline 6 & If & $\mathrm{C}$ is $\mathrm{C}_{1}$ & and & $\mathrm{t}$ is $\mathrm{t}_{6}$ & then & $\mathrm{T}$ is $\mathrm{T}_{3}$ & 47 & If & $\mathrm{C}$ is $\mathrm{C}_{6}$ & and & $\mathrm{t}$ is $\mathrm{t}_{2}$ & then & $\mathrm{T}$ is $\mathrm{T}_{3}$ \\
\hline 7 & If & $\mathrm{C}$ is $\mathrm{C}_{1}$ & and & $\mathrm{t}$ is $\mathrm{t}_{7}$ & then & $\mathrm{T}$ is $\mathrm{T}_{3}$ & 48 & If & $\mathrm{C}$ is $\mathrm{C}_{6}$ & and & $\mathrm{t}$ is $\mathrm{t}_{3}$ & then & $\mathrm{T}$ is $\mathrm{T}_{3}$ \\
\hline 8 & If & $\mathrm{C}$ is $\mathrm{C}_{1}$ & and & $\mathrm{t}$ is $\mathrm{t}_{8}$ & then & $\mathrm{T}$ is $\mathrm{T}_{3}$ & 49 & If & $\mathrm{C}$ is $\mathrm{C}_{6}$ & and & $\mathrm{t}$ is $\mathrm{t}_{4}$ & then & $\mathrm{T}$ is $\mathrm{T}_{4}$ \\
\hline 9 & If & $\mathrm{C}$ is $\mathrm{C}_{1}$ & and & $\mathrm{t}$ is $\mathrm{t} 9$ & then & $\mathrm{T}$ is $\mathrm{T}_{4}$ & 50 & If & $\mathrm{C}$ is $\mathrm{C}_{6}$ & and & $\mathrm{t}$ is $\mathrm{t}_{5}$ & then & $\mathrm{T}$ is $\mathrm{T}_{5}$ \\
\hline 10 & If & $\mathrm{C}$ is $\mathrm{C}_{2}$ & and & $\mathrm{t}$ is $\mathrm{t}_{1}$ & then & $\mathrm{T}$ is $\mathrm{T}_{2}$ & 51 & If & $\mathrm{C}$ is $\mathrm{C}_{6}$ & and & $\mathrm{t}$ is $\mathrm{t}_{6}$ & then & $\mathrm{T}$ is $\mathrm{T}_{5}$ \\
\hline 11 & If & $\mathrm{C}$ is $\mathrm{C}_{2}$ & and & $\mathrm{t}$ is $\mathrm{t}_{2}$ & then & $\mathrm{T}$ is $\mathrm{T}_{3}$ & 52 & If & $\mathrm{C}$ is $\mathrm{C}_{6}$ & and & $\mathrm{t}$ is $\mathrm{t}_{7}$ & then & $\mathrm{T}$ is $\mathrm{T}_{7}$ \\
\hline 12 & If & $\mathrm{C}$ is $\mathrm{C}_{2}$ & and & $\mathrm{t}$ is $\mathrm{t}_{3}$ & then & $\mathrm{T}$ is $\mathrm{T}_{3}$ & 53 & If & $\mathrm{C}$ is $\mathrm{C}_{6}$ & and & $\mathrm{t}$ is $\mathrm{t} 8$ & then & $\mathrm{T}$ is $\mathrm{T}_{8}$ \\
\hline 13 & If & $\mathrm{C}$ is $\mathrm{C}_{2}$ & and & $\mathrm{t}$ is $\mathrm{t}_{4}$ & then & $\mathrm{T}$ is $\mathrm{T}_{4}$ & 54 & If & $\mathrm{C}$ is $\mathrm{C}_{6}$ & and & $\mathrm{t}$ is $\mathrm{t}_{9}$ & then & $\mathrm{T}$ is $\mathrm{T}_{9}$ \\
\hline 14 & If & $\mathrm{C}$ is $\mathrm{C}_{2}$ & and & $\mathrm{t}$ is $\mathrm{t}_{5}$ & then & $\mathrm{T}$ is $\mathrm{T}_{4}$ & 55 & If & $\mathrm{C}$ is $\mathrm{C}_{7}$ & and & $t$ is $t_{1}$ & then & $\mathrm{T}$ is $\mathrm{T}_{1}$ \\
\hline 15 & If & $\mathrm{C}$ is $\mathrm{C}_{2}$ & and & $\mathrm{t}$ is $\mathrm{t}_{6}$ & then & $\mathrm{T}$ is $\mathrm{T}_{4}$ & 56 & If & $\mathrm{C}$ is $\mathrm{C}_{7}$ & and & $\mathrm{t}$ is $\mathrm{t}_{2}$ & then & $\mathrm{T}$ is $\mathrm{T}_{2}$ \\
\hline 16 & If & $\mathrm{C}$ is $\mathrm{C}_{2}$ & and & $\mathrm{t}$ is $\mathrm{t} 7$ & then & $\mathrm{T}$ is $\mathrm{T}_{5}$ & 57 & If & $\mathrm{C}$ is $\mathrm{C}_{7}$ & and & $\mathrm{t}$ is $\mathrm{t}_{3}$ & then & $\mathrm{T}$ is $\mathrm{T}_{2}$ \\
\hline 17 & If & $\mathrm{C}$ is $\mathrm{C}_{2}$ & and & $\mathrm{t}$ is $\mathrm{t}_{8}$ & then & $\mathrm{T}$ is $\mathrm{T}_{5}$ & 58 & If & $\mathrm{C}$ is $\mathrm{C}_{7}$ & and & $\mathrm{t}$ is $\mathrm{t}_{4}$ & then & $\mathrm{T}$ is $\mathrm{T}_{3}$ \\
\hline 18 & If & $\mathrm{C}$ is $\mathrm{C}_{2}$ & and & $\mathrm{t}$ is $\mathrm{t} 9$ & then & $\mathrm{T}$ is $\mathrm{T}_{6}$ & 59 & If & $\mathrm{C}$ is $\mathrm{C}_{7}$ & and & $\mathrm{t}$ is $\mathrm{t}_{5}$ & then & $\mathrm{T}$ is $\mathrm{T}_{3}$ \\
\hline 19 & If & $\mathrm{C}$ is $\mathrm{C}_{3}$ & and & $\mathrm{t}$ is $\mathrm{t}_{1}$ & then & $\mathrm{T}$ is $\mathrm{T}_{3}$ & 60 & If & $\mathrm{C}$ is $\mathrm{C}_{7}$ & and & $t$ is $t_{6}$ & then & $\mathrm{T}$ is $\mathrm{T}_{3}$ \\
\hline 20 & If & $\mathrm{C}$ is $\mathrm{C}_{3}$ & and & $\mathrm{t}$ is $\mathrm{t}_{2}$ & then & $\mathrm{T}$ is $\mathrm{T}_{4}$ & 61 & If & $\mathrm{C}$ is $\mathrm{C}_{7}$ & and & $t$ is $t_{7}$ & then & $\mathrm{T}$ is $\mathrm{T}_{4}$ \\
\hline 21 & If & $\mathrm{C}$ is $\mathrm{C}_{3}$ & and & $\mathrm{t}$ is $\mathrm{t} 3$ & then & $\mathrm{T}$ is $\mathrm{T}_{4}$ & 62 & If & $\mathrm{C}$ is $\mathrm{C}_{7}$ & and & $\mathrm{t}$ is $\mathrm{t} 8$ & then & $\mathrm{T}$ is $\mathrm{T}_{4}$ \\
\hline 22 & If & $\mathrm{C}$ is $\mathrm{C}_{3}$ & and & $\mathrm{t}$ is $\mathrm{t}_{4}$ & then & $\mathrm{T}$ is $\mathrm{T}_{4}$ & 63 & If & $\mathrm{C}$ is $\mathrm{C}_{7}$ & and & $\mathrm{t}$ is $\mathrm{t} 9$ & then & $\mathrm{T}$ is $\mathrm{T}_{5}$ \\
\hline 23 & If & $\mathrm{C}$ is $\mathrm{C}_{3}$ & and & $\mathrm{t}$ is $\mathrm{t}_{5}$ & then & $\mathrm{T}$ is $\mathrm{T}_{5}$ & 64 & If & $\mathrm{C}$ is $\mathrm{C}_{8}$ & and & $t$ is $t_{1}$ & then & $\mathrm{T}$ is $\mathrm{T}_{1}$ \\
\hline 24 & If & $\mathrm{C}$ is $\mathrm{C}_{3}$ & and & $\mathrm{t}$ is $\mathrm{t}_{6}$ & then & $\mathrm{T}$ is $\mathrm{T}_{5}$ & 65 & If & $\mathrm{C}$ is $\mathrm{C}_{8}$ & and & $\mathrm{t}$ is $\mathrm{t}_{2}$ & then & $\mathrm{T}$ is $\mathrm{T}_{1}$ \\
\hline 25 & If & $\mathrm{C}$ is $\mathrm{C}_{3}$ & and & $\mathrm{t}$ is $\mathrm{t}_{7}$ & then & $\mathrm{T}$ is $\mathrm{T}_{6}$ & 66 & If & $\mathrm{C}$ is $\mathrm{C}_{8}$ & and & $\mathrm{t}$ is $\mathrm{t}_{3}$ & then & $\mathrm{T}$ is $\mathrm{T}_{1}$ \\
\hline 26 & If & $\mathrm{C}$ is $\mathrm{C}_{3}$ & and & $\mathrm{t}$ is $\mathrm{t}_{8}$ & then & $\mathrm{T}$ is $\mathrm{T}_{6}$ & 67 & If & $\mathrm{C}$ is $\mathrm{C}_{8}$ & and & $\mathrm{t}$ is $\mathrm{t}_{4}$ & then & $\mathrm{T}$ is $\mathrm{T}_{1}$ \\
\hline 27 & If & $\mathrm{C}$ is $\mathrm{C}_{3}$ & and & $\mathrm{t}$ is $\mathrm{t} 9$ & then & $\mathrm{T}$ is $\mathrm{T}_{7}$ & 68 & If & $\mathrm{C}$ is $\mathrm{C}_{8}$ & and & $\mathrm{t}$ is $\mathrm{t}_{5}$ & then & $\mathrm{T}$ is $\mathrm{T}_{1}$ \\
\hline 28 & If & $\mathrm{C}$ is $\mathrm{C}_{4}$ & and & $\mathrm{t}$ is $\mathrm{t}_{1}$ & then & $\mathrm{T}$ is $\mathrm{T}_{3}$ & 69 & If & $\mathrm{C}$ is $\mathrm{C}_{8}$ & and & $\mathrm{t}$ is $\mathrm{t}_{6}$ & then & $\mathrm{T}$ is $\mathrm{T}_{2}$ \\
\hline 29 & If & $\mathrm{C}$ is $\mathrm{C}_{4}$ & and & $\mathrm{t}$ is $\mathrm{t}_{2}$ & then & $\mathrm{T}$ is $\mathrm{T}_{3}$ & 70 & If & $\mathrm{C}$ is $\mathrm{C}_{8}$ & and & $\mathrm{t}$ is $\mathrm{t}_{7}$ & then & $\mathrm{T}$ is $\mathrm{T}_{2}$ \\
\hline 30 & If & $\mathrm{C}$ is $\mathrm{C}_{4}$ & and & $\mathrm{t}$ is $\mathrm{t}_{3}$ & then & $\mathrm{T}$ is $\mathrm{T}_{4}$ & 71 & If & $\mathrm{C}$ is $\mathrm{C}_{8}$ & and & $\mathrm{t}$ is $\mathrm{t} 8$ & then & $\mathrm{T}$ is $\mathrm{T}_{2}$ \\
\hline 31 & If & $\mathrm{C}$ is $\mathrm{C}_{4}$ & and & $\mathrm{t}$ is $\mathrm{t}_{4}$ & then & $\mathrm{T}$ is $\mathrm{T}_{5}$ & 72 & If & $\mathrm{C}$ is $\mathrm{C}_{8}$ & and & $\mathrm{t}$ is $\mathrm{t}_{9}$ & then & $\mathrm{T}$ is $\mathrm{T}_{2}$ \\
\hline 32 & If & $\mathrm{C}$ is $\mathrm{C}_{4}$ & and & $\mathrm{t}$ is $\mathrm{t}_{5}$ & then & $\mathrm{T}$ is $\mathrm{T}_{5}$ & 73 & If & $\mathrm{C}$ is $\mathrm{C}_{9}$ & and & $t$ is $t_{1}$ & then & $\mathrm{T}$ is $\mathrm{T}_{1}$ \\
\hline 33 & If & $\mathrm{C}$ is $\mathrm{C}_{4}$ & and & $\mathrm{t}$ is $\mathrm{t}_{6}$ & then & $\mathrm{T}$ is $\mathrm{T}_{6}$ & 74 & If & $\mathrm{C}$ is $\mathrm{C}_{9}$ & and & $\mathrm{t}$ is $\mathrm{t}_{2}$ & then & $\mathrm{T}$ is $\mathrm{T}_{2}$ \\
\hline 34 & If & $\mathrm{C}$ is $\mathrm{C}_{4}$ & and & $\mathrm{t}$ is $\mathrm{t}_{7}$ & then & $\mathrm{T}$ is $\mathrm{T}_{7}$ & 75 & If & $\mathrm{C}$ is $\mathrm{C}_{9}$ & and & $\mathrm{t}$ is $\mathrm{t}_{3}$ & then & $\mathrm{T}$ is $\mathrm{T}_{2}$ \\
\hline 35 & If & $\mathrm{C}$ is $\mathrm{C}_{4}$ & and & $\mathrm{t}$ is $\mathrm{t}_{8}$ & then & $\mathrm{T}$ is $\mathrm{T}_{8}$ & 76 & If & $\mathrm{C}$ is $\mathrm{C}_{9}$ & and & $\mathrm{t}$ is $\mathrm{t}_{4}$ & then & $\mathrm{T}$ is $\mathrm{T}_{3}$ \\
\hline 36 & If & $\mathrm{C}$ is $\mathrm{C}_{4}$ & and & $\mathrm{t}$ is $\mathrm{t} 9$ & then & $\mathrm{T}$ is $\mathrm{T}_{9}$ & 77 & If & $\mathrm{C}$ is $\mathrm{C}_{9}$ & and & $\mathrm{t}$ is $\mathrm{t}_{5}$ & then & $\mathrm{T}$ is $\mathrm{T}_{3}$ \\
\hline 37 & If & $\mathrm{C}$ is $\mathrm{C}_{5}$ & and & $t$ is $t_{1}$ & then & $\mathrm{T}$ is $\mathrm{T}_{3}$ & 78 & If & $\mathrm{C}$ is $\mathrm{C}_{9}$ & and & $\mathrm{t}$ is $\mathrm{t}_{6}$ & then & $\mathrm{T}$ is $\mathrm{T}_{3}$ \\
\hline 38 & If & $\mathrm{C}$ is $\mathrm{C}_{5}$ & and & $t$ is $t_{2}$ & then & $\mathrm{T}$ is $\mathrm{T}_{3}$ & 79 & If & $\mathrm{C}$ is $\mathrm{C}_{9}$ & and & $\mathrm{t}$ is $\mathrm{t}_{7}$ & then & $\mathrm{T}$ is $\mathrm{T}_{3}$ \\
\hline 39 & If & $\mathrm{C}$ is $\mathrm{C}_{5}$ & and & $\mathrm{t}$ is $\mathrm{t} 3$ & then & $\mathrm{T}$ is $\mathrm{T}_{4}$ & 80 & If & $\mathrm{C}$ is $\mathrm{C}_{9}$ & and & $\mathrm{t}$ is $\mathrm{t} 8$ & then & $\mathrm{T}$ is $\mathrm{T}_{3}$ \\
\hline 40 & If & $\mathrm{C}$ is $\mathrm{C}_{5}$ & and & $\mathrm{t}$ is $\mathrm{t}_{4}$ & then & $\mathrm{T}$ is $\mathrm{T}_{5}$ & 81 & If & $\mathrm{C}$ is $\mathrm{C}_{9}$ & and & $\mathrm{t}$ is $\mathrm{t}_{9}$ & then & $\mathrm{T}$ is $\mathrm{T}_{3}$ \\
\hline 41 & If & $\mathrm{C}$ is $\mathrm{C}_{5}$ & and & $\mathrm{t}$ is $\mathrm{t}_{5}$ & then & $\mathrm{T}$ is $\mathrm{T}_{6}$ & & & & & & & \\
\hline
\end{tabular}


Table 5. Rules of RBMTF for Flow Rate $(\mathrm{g} / \mathrm{h})$

\begin{tabular}{|c|c|c|c|c|c|c|c|c|c|c|c|c|c|}
\hline $\begin{array}{c}\text { Rule } \\
\text { number }\end{array}$ & & $\mathrm{C}$ & & $\mathbf{t}$ & & FR & $\begin{array}{c}\text { Rule } \\
\text { number }\end{array}$ & If & $\mathrm{C}$ & and & $t$ & then & FR \\
\hline 1 & If & $\mathrm{C}$ is $\mathrm{C}_{1}$ & and & $t$ is $t_{1}$ & then & $\mathrm{FR}$ is $\mathrm{FR}_{1}$ & 42 & If & $\mathrm{C}$ is $\mathrm{C}_{5}$ & and & $\mathrm{t}$ is $\mathrm{t}_{6}$ & then & $\mathrm{FR}$ is $\mathrm{FR}_{5}$ \\
\hline 2 & If & $\mathrm{C}$ is $\mathrm{C}_{1}$ & and & $\mathrm{t}$ is $\mathrm{t}_{2}$ & then & $\mathrm{FR}$ is $\mathrm{FR}_{1}$ & 43 & If & $\mathrm{C}$ is $\mathrm{C}_{5}$ & and & $\mathrm{t}$ is $\mathrm{t} 7$ & then & $\mathrm{FR}$ is $\mathrm{FR}_{5}$ \\
\hline 3 & If & $\mathrm{C}$ is $\mathrm{C}_{1}$ & and & $t$ is $t_{3}$ & then & $\mathrm{FR}$ is $\mathrm{FR}_{1}$ & 44 & If & $\mathrm{C}$ is $\mathrm{C}_{5}$ & and & $\mathrm{t}$ is $\mathrm{t}_{8}$ & then & $\mathrm{FR}$ is $\mathrm{FR}_{5}$ \\
\hline 4 & If & $\mathrm{C}$ is $\mathrm{C}_{1}$ & and & $\mathrm{t}$ is $\mathrm{t}_{4}$ & then & $\mathrm{FR}$ is $\mathrm{FR}_{1}$ & 45 & If & $\mathrm{C}$ is $\mathrm{C}_{5}$ & and & $\mathrm{t}$ is $\mathrm{t} 9$ & then & $\mathrm{FR}$ is $\mathrm{FR}_{5}$ \\
\hline 5 & If & $\mathrm{C}$ is $\mathrm{C}_{1}$ & and & $\mathrm{t}$ is $\mathrm{t}_{5}$ & then & $\mathrm{FR}$ is $\mathrm{FR}_{1}$ & 46 & If & $\mathrm{C}$ is $\mathrm{C}_{6}$ & and & $\mathrm{t}$ is $\mathrm{t}_{1}$ & then & $\mathrm{FR}$ is $\mathrm{FR}_{6}$ \\
\hline 6 & If & $\mathrm{C}$ is $\mathrm{C}_{1}$ & and & $t_{\text {is }} t_{6}$ & then & $\mathrm{FR}$ is $\mathrm{FR}_{1}$ & 47 & If & $\mathrm{C}$ is $\mathrm{C}_{6}$ & and & $\mathrm{t}$ is $\mathrm{t}_{2}$ & then & $\mathrm{FR}$ is $\mathrm{FR}_{6}$ \\
\hline 7 & If & $\mathrm{C}$ is $\mathrm{C}_{1}$ & and & $\mathrm{t}$ is $\mathrm{t} 7$ & then & $\mathrm{FR}$ is $\mathrm{FR}_{1}$ & 48 & If & $\mathrm{C}$ is $\mathrm{C}_{6}$ & and & $\mathrm{t}$ is $\mathrm{t}_{3}$ & then & $\mathrm{FR}$ is $\mathrm{FR}_{6}$ \\
\hline 8 & If & $\mathrm{C}$ is $\mathrm{C}_{1}$ & and & $\mathrm{t}$ is $\mathrm{t} 8$ & then & $\mathrm{FR}$ is $\mathrm{FR}_{1}$ & 49 & If & $\mathrm{C}$ is $\mathrm{C}_{6}$ & and & $\mathrm{t}$ is $\mathrm{t}_{4}$ & then & $\mathrm{FR}$ is $\mathrm{FR}_{6}$ \\
\hline 9 & If & $\mathrm{C}$ is $\mathrm{C}_{1}$ & and & $\mathrm{t}$ is $\mathrm{t} 9$ & then & $\mathrm{FR}$ is $\mathrm{FR}_{1}$ & 50 & If & $\mathrm{C}$ is $\mathrm{C}_{6}$ & and & $t$ is $t_{5}$ & then & $\mathrm{FR}$ is $\mathrm{FR}_{6}$ \\
\hline 10 & If & $\mathrm{C}$ is $\mathrm{C}_{2}$ & and & $t$ is $t_{1}$ & then & $\mathrm{FR}$ is $\mathrm{FR}_{2}$ & 51 & If & $\mathrm{C}$ is $\mathrm{C}_{6}$ & and & $\mathrm{t}$ is $\mathrm{t}_{6}$ & then & $\mathrm{FR}$ is $\mathrm{FR}_{6}$ \\
\hline 11 & If & $\mathrm{C}$ is $\mathrm{C}_{2}$ & and & $\mathrm{t}$ is $\mathrm{t}_{2}$ & then & $\mathrm{FR}$ is $\mathrm{FR}_{2}$ & 52 & If & $\mathrm{C}$ is $\mathrm{C}_{6}$ & and & $\mathrm{t}$ is $\mathrm{t}_{7}$ & then & $\mathrm{FR}$ is $\mathrm{FR}_{6}$ \\
\hline 12 & If & $\mathrm{C}$ is $\mathrm{C}_{2}$ & and & $\mathrm{t}$ is $\mathrm{t} 3$ & then & $\mathrm{FR}$ is $\mathrm{FR}_{2}$ & 53 & If & $\mathrm{C}$ is $\mathrm{C}_{6}$ & and & $\mathrm{t}$ is $\mathrm{t}_{8}$ & then & $\mathrm{FR}$ is $\mathrm{FR}_{6}$ \\
\hline 13 & If & $\mathrm{C}$ is $\mathrm{C}_{2}$ & and & $\mathrm{t}$ is $\mathrm{t}_{4}$ & then & $\mathrm{FR}$ is $\mathrm{FR}_{2}$ & 54 & If & $\mathrm{C}$ is $\mathrm{C}_{6}$ & and & $\mathrm{t}$ is $\mathrm{t}_{9}$ & then & $\mathrm{FR}$ is $\mathrm{FR}_{6}$ \\
\hline 14 & If & $\mathrm{C}$ is $\mathrm{C}_{2}$ & and & $t$ is $t_{5}$ & then & $\mathrm{FR}$ is $\mathrm{FR}_{2}$ & 55 & If & $\mathrm{C}$ is $\mathrm{C}_{7}$ & and & $\mathrm{t}$ is $\mathrm{t}_{1}$ & then & $\mathrm{FR}$ is $\mathrm{FR}$ \\
\hline 15 & If & $\mathrm{C}$ is $\mathrm{C}_{2}$ & and & $t$ is $t_{6}$ & then & $\mathrm{FR}$ is $\mathrm{FR}_{2}$ & 56 & If & $\mathrm{C}$ is $\mathrm{C}_{7}$ & and & $\mathrm{t}$ is $\mathrm{t}_{2}$ & then & $\mathrm{FR}$ is $\mathrm{FR}$ \\
\hline 16 & If & $\mathrm{C}$ is $\mathrm{C}_{2}$ & and & $\mathrm{t}$ is $\mathrm{t} 7$ & then & $\mathrm{FR}$ is $\mathrm{FR}_{2}$ & 57 & If & $\mathrm{C}$ is $\mathrm{C}_{7}$ & and & $t$ is $t_{3}$ & then & $\mathrm{FR}$ is $\mathrm{FR} 7$ \\
\hline 17 & If & $\mathrm{C}$ is $\mathrm{C}_{2}$ & and & $\mathrm{t}$ is $\mathrm{t}_{8}$ & then & $\mathrm{FR}$ is $\mathrm{FR}_{2}$ & 58 & If & $\mathrm{C}$ is $\mathrm{C}_{7}$ & and & $\mathrm{t}$ is $\mathrm{t}_{4}$ & then & $\mathrm{FR}$ is $\mathrm{FR} 7$ \\
\hline 18 & If & $\mathrm{C}$ is $\mathrm{C}_{2}$ & and & $\mathrm{t}$ is $\mathrm{t}_{9}$ & then & $\mathrm{FR}$ is $\mathrm{FR}_{2}$ & 59 & If & $\mathrm{C}$ is $\mathrm{C}_{7}$ & and & $t$ is $t_{5}$ & then & $\mathrm{FR}$ is $\mathrm{FR}$ \\
\hline 19 & If & $\mathrm{C}$ is $\mathrm{C}_{3}$ & and & $\mathrm{t}$ is $\mathrm{t}_{1}$ & then & $\mathrm{FR}$ is $\mathrm{FR}_{3}$ & 60 & If & $\mathrm{C}$ is $\mathrm{C}_{7}$ & and & $\mathrm{t}_{\text {is }} \mathrm{t}_{6}$ & then & $\mathrm{FR}$ is $\mathrm{FR}$ ? \\
\hline 20 & If & $\mathrm{C}$ is $\mathrm{C}_{3}$ & and & $\mathrm{t}$ is $\mathrm{t}_{2}$ & then & $\mathrm{FR}$ is $\mathrm{FR}_{3}$ & 61 & If & $\mathrm{C}$ is $\mathrm{C}_{7}$ & and & $\mathrm{t}$ is $\mathrm{t}_{7}$ & then & $\mathrm{FR}$ is $\mathrm{FR} 7$ \\
\hline 21 & If & $\mathrm{C}$ is $\mathrm{C}_{3}$ & and & $\mathrm{t}_{\text {is }} \mathrm{t}_{3}$ & then & $\mathrm{FR}$ is $\mathrm{FR}_{3}$ & 62 & If & $\mathrm{C}$ is $\mathrm{C}_{7}$ & and & $\mathrm{t}$ is $\mathrm{t}_{8}$ & then & $\mathrm{FR}$ is $\mathrm{FR}$ \\
\hline 22 & If & $\mathrm{C}$ is $\mathrm{C}_{3}$ & and & $\mathrm{t}$ is $\mathrm{t}_{4}$ & then & $\mathrm{FR}$ is $\mathrm{FR}_{3}$ & 63 & If & $\mathrm{C}$ is $\mathrm{C}_{7}$ & and & $\mathrm{t}$ is $\mathrm{t}_{9}$ & then & $\mathrm{FR}$ is $\mathrm{FR}$ ? \\
\hline 23 & If & $\mathrm{C}$ is $\mathrm{C}_{3}$ & and & $t$ is $t_{5}$ & then & $\mathrm{FR}$ is $\mathrm{FR}_{3}$ & 64 & If & $\mathrm{C}$ is $\mathrm{C}_{8}$ & and & $\mathrm{t}$ is $\mathrm{t}_{1}$ & then & $\mathrm{FR}$ is $\mathrm{FR} 7$ \\
\hline 24 & If & $\mathrm{C}$ is $\mathrm{C}_{3}$ & and & $\mathrm{t}$ is $\mathrm{t}_{6}$ & then & $\mathrm{FR}$ is $\mathrm{FR}_{3}$ & 65 & If & $\mathrm{C}$ is $\mathrm{C}_{8}$ & and & $\mathrm{t}$ is $\mathrm{t}_{2}$ & then & $\mathrm{FR}$ is $\mathrm{FR}$ ? \\
\hline 25 & If & $\mathrm{C}$ is $\mathrm{C}_{3}$ & and & $\mathrm{t}$ is $\mathrm{t} 7$ & then & $\mathrm{FR}$ is $\mathrm{FR}_{3}$ & 66 & If & $\mathrm{C}$ is $\mathrm{C}_{8}$ & and & $t$ is $t_{3}$ & then & $\mathrm{FR}$ is $\mathrm{FR}$ ? \\
\hline 26 & If & $\mathrm{C}$ is $\mathrm{C}_{3}$ & and & $\mathrm{t}$ is $\mathrm{t}_{8}$ & then & $\mathrm{FR}$ is $\mathrm{FR}_{3}$ & 67 & If & $\mathrm{C}$ is $\mathrm{C}_{8}$ & and & $\mathrm{t}$ is $\mathrm{t}_{4}$ & then & $\mathrm{FR}$ is $\mathrm{FR}$ ? \\
\hline 27 & If & $\mathrm{C}$ is $\mathrm{C}_{3}$ & and & $\mathrm{t}$ is $\mathrm{t} 9$ & then & $\mathrm{FR}$ is $\mathrm{FR}_{3}$ & 68 & If & $\mathrm{C}$ is $\mathrm{C}_{8}$ & and & $t$ is $t_{5}$ & then & $\mathrm{FR}$ is $\mathrm{FR} 7$ \\
\hline 28 & If & $\mathrm{C}$ is $\mathrm{C}_{4}$ & and & $\mathrm{t}$ is $\mathrm{t}_{1}$ & then & $\mathrm{FR}$ is $\mathrm{FR}_{5}$ & 69 & If & $\mathrm{C}$ is $\mathrm{C}_{8}$ & and & $\mathrm{t}$ is $\mathrm{t}_{6}$ & then & $\mathrm{FR}$ is $\mathrm{FR}$ \\
\hline 29 & If & $\mathrm{C}$ is $\mathrm{C}_{4}$ & and & $t$ is $t_{2}$ & then & $\mathrm{FR}$ is $\mathrm{FR}_{4}$ & 70 & If & $\mathrm{C}$ is $\mathrm{C}_{8}$ & and & $\mathrm{t}$ is $\mathrm{t} 7$ & then & $\mathrm{FR}$ is $\mathrm{FR}$ \\
\hline 30 & If & $\mathrm{C}$ is $\mathrm{C}_{4}$ & and & $t_{\text {is }} t_{3}$ & then & $\mathrm{FR}$ is $\mathrm{FR}_{4}$ & 71 & If & $\mathrm{C}$ is $\mathrm{C}_{8}$ & and & $\mathrm{t}$ is $\mathrm{t}_{8}$ & then & $\mathrm{FR}$ is $\mathrm{FR} 7$ \\
\hline 31 & If & $\mathrm{C}$ is $\mathrm{C}_{4}$ & and & $\mathrm{t}$ is $\mathrm{t}_{4}$ & then & $\mathrm{FR}$ is $\mathrm{FR}_{4}$ & 72 & If & $\mathrm{C}$ is $\mathrm{C}_{8}$ & and & $\mathrm{t}$ is $\mathrm{t}_{9}$ & then & $\mathrm{FR}$ is $\mathrm{FR}$ ? \\
\hline 32 & If & $\mathrm{C}$ is $\mathrm{C}_{4}$ & and & $t$ is $t_{5}$ & then & $\mathrm{FR}$ is $\mathrm{FR}_{4}$ & 73 & If & $\mathrm{C}$ is $\mathrm{C}_{9}$ & and & $t$ is $t_{1}$ & then & $\mathrm{FR}$ is $\mathrm{FR}$ \\
\hline 33 & If & $\mathrm{C}$ is $\mathrm{C}_{4}$ & and & $\mathrm{t}$ is $\mathrm{t}_{6}$ & then & $\mathrm{FR}$ is $\mathrm{FR}_{4}$ & 74 & If & $\mathrm{C}$ is $\mathrm{C}_{9}$ & and & $\mathrm{t}$ is $\mathrm{t}_{2}$ & then & $\mathrm{FR}$ is $\mathrm{FR}$ ? \\
\hline 34 & If & $\mathrm{C}$ is $\mathrm{C}_{4}$ & and & $\mathrm{t}$ is $\mathrm{t} 7$ & then & $\mathrm{FR}$ is $\mathrm{FR}_{4}$ & 75 & If & $\mathrm{C}$ is $\mathrm{C}_{9}$ & and & $\mathrm{t}$ is $\mathrm{t}_{3}$ & then & $\mathrm{FR}$ is $\mathrm{FR} 7$ \\
\hline 35 & If & $\mathrm{C}$ is $\mathrm{C}_{4}$ & and & $\mathrm{t}$ is $\mathrm{t}_{8}$ & then & $\mathrm{FR}$ is $\mathrm{FR}_{4}$ & 76 & If & $\mathrm{C}$ is $\mathrm{C}_{9}$ & and & $\mathrm{t}$ is $\mathrm{t}_{4}$ & then & $\mathrm{FR}$ is $\mathrm{FR}$ ? \\
\hline 36 & If & $\mathrm{C}$ is $\mathrm{C}_{4}$ & and & $\mathrm{t}$ is $\mathrm{t}_{9}$ & then & $\mathrm{FR}$ is $\mathrm{FR}_{4}$ & 77 & If & $\mathrm{C}$ is $\mathrm{C}_{9}$ & and & $\mathrm{t}$ is $\mathrm{t}_{5}$ & then & $\mathrm{FR}$ is $\mathrm{FR}$ ? \\
\hline 37 & If & $\mathrm{C}$ is $\mathrm{C}_{5}$ & and & $\mathrm{t}$ is $\mathrm{t}_{1}$ & then & $\mathrm{FR}$ is $\mathrm{FR}_{6}$ & 78 & If & $\mathrm{C}$ is $\mathrm{C}_{9}$ & and & $\mathrm{t}$ is $\mathrm{t}_{6}$ & then & $\mathrm{FR}$ is $\mathrm{FR}$ ? \\
\hline 38 & If & $\mathrm{C}$ is $\mathrm{C}_{5}$ & and & $t$ is $t_{2}$ & then & $\mathrm{FR}$ is $\mathrm{FR}_{5}$ & 79 & If & $\mathrm{C}$ is $\mathrm{C}_{9}$ & and & $\mathrm{t}$ is $\mathrm{t} 7$ & then & $\mathrm{FR}$ is $\mathrm{FR}$ ? \\
\hline 39 & If & $\mathrm{C}$ is $\mathrm{C}_{5}$ & and & $t$ is $t_{3}$ & then & $\mathrm{FR}$ is $\mathrm{FR}_{5}$ & 80 & If & $\mathrm{C}$ is $\mathrm{C}_{9}$ & and & $\mathrm{t}$ is $\mathrm{t}_{8}$ & then & $\mathrm{FR}$ is $\mathrm{FR}$ ? \\
\hline 40 & If & $\mathrm{C}$ is $\mathrm{C}_{5}$ & and & $\mathrm{t}$ is $\mathrm{t}_{4}$ & then & $\mathrm{FR}$ is $\mathrm{FR}_{5}$ & 81 & If & $\mathrm{C}$ is $\mathrm{C}_{9}$ & and & $\mathrm{t}$ is $\mathrm{t} 9$ & then & $\mathrm{FR}$ is $\mathrm{FR} 7$ \\
\hline 41 & If & $\mathrm{C}$ is $\mathrm{C}_{5}$ & and & $\mathrm{t}$ is $\mathrm{t}_{5}$ & then & $\mathrm{FR}$ is $\mathrm{FR}_{5}$ & & & & & & & \\
\hline
\end{tabular}




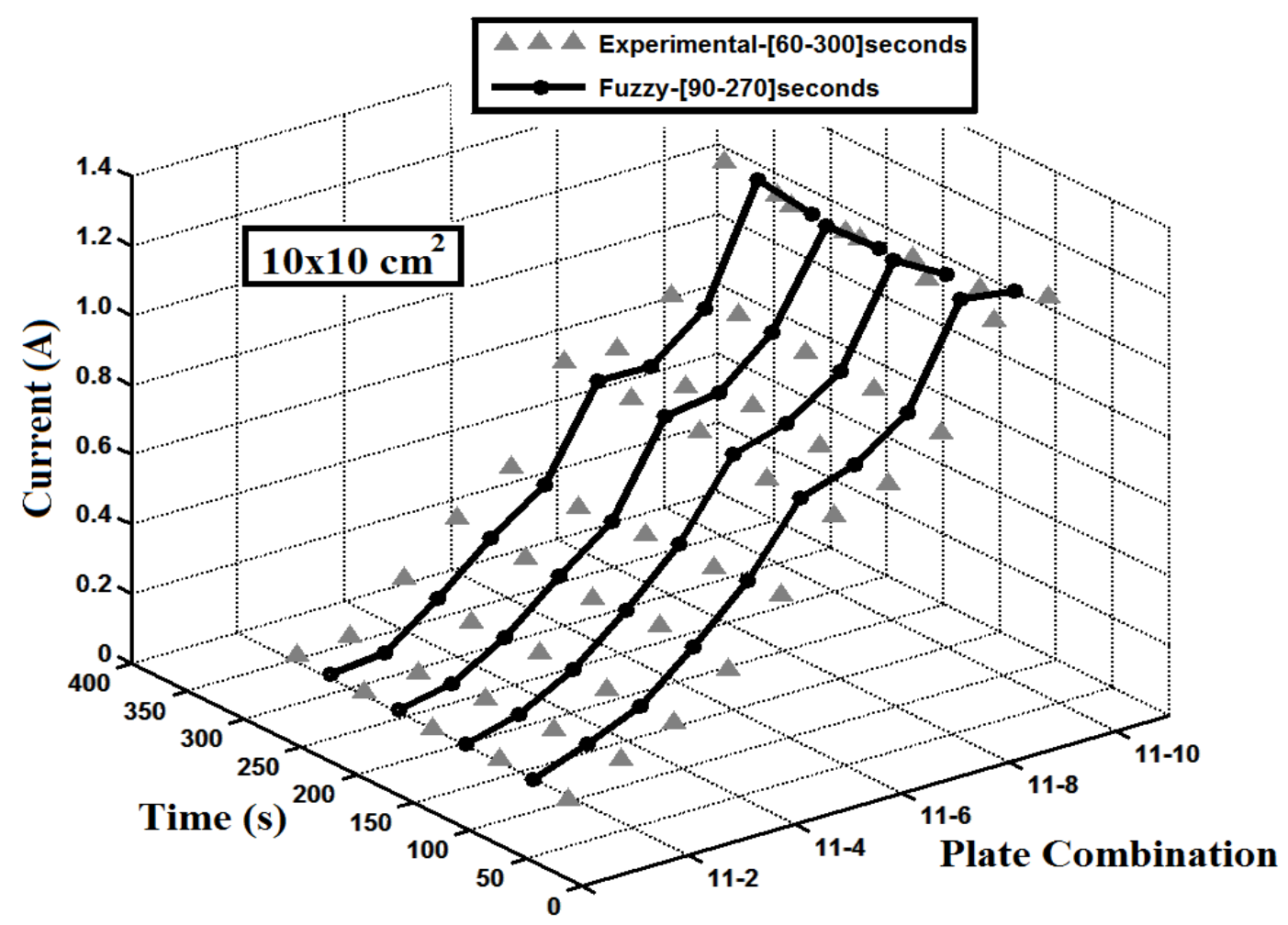

(a)

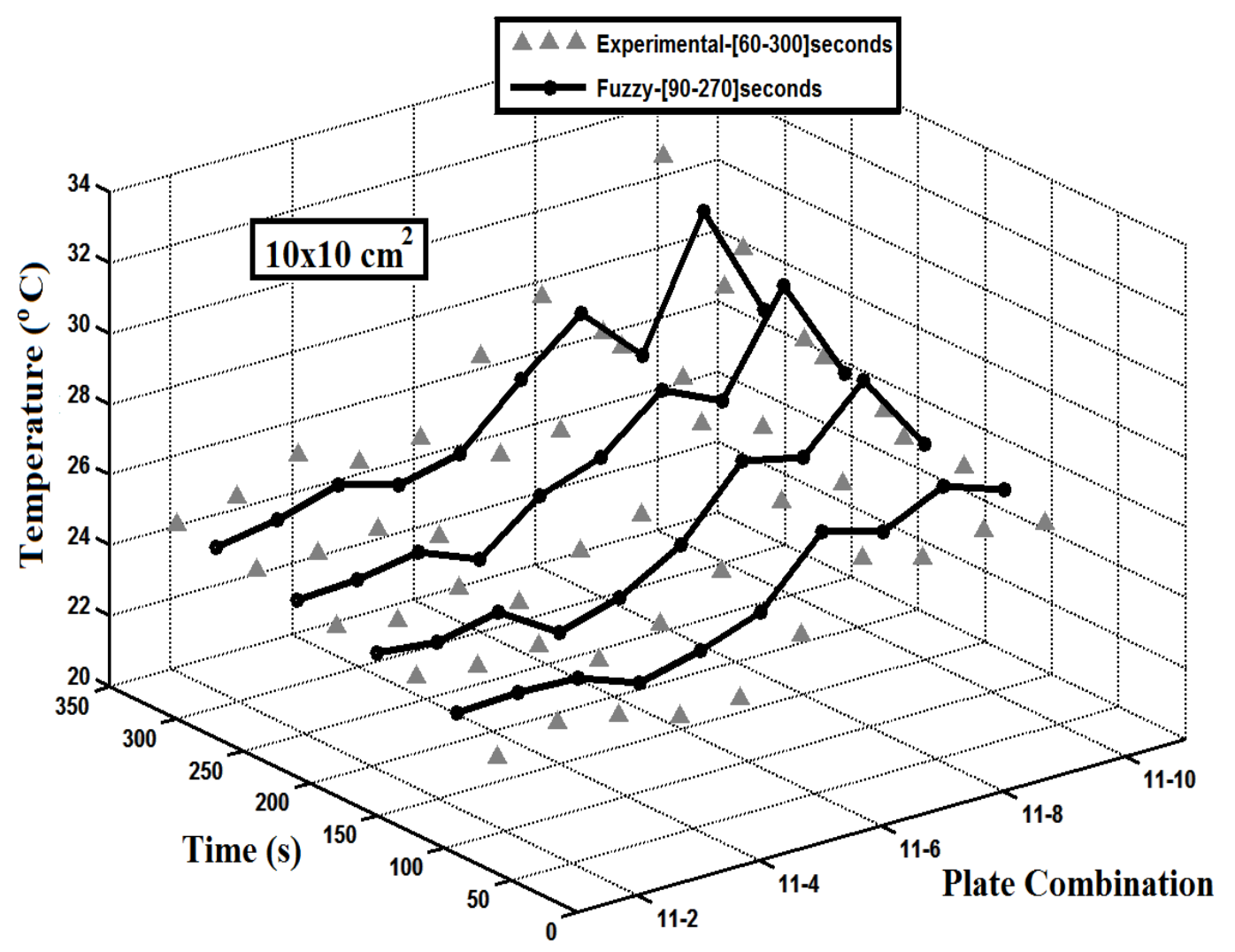

(b) 


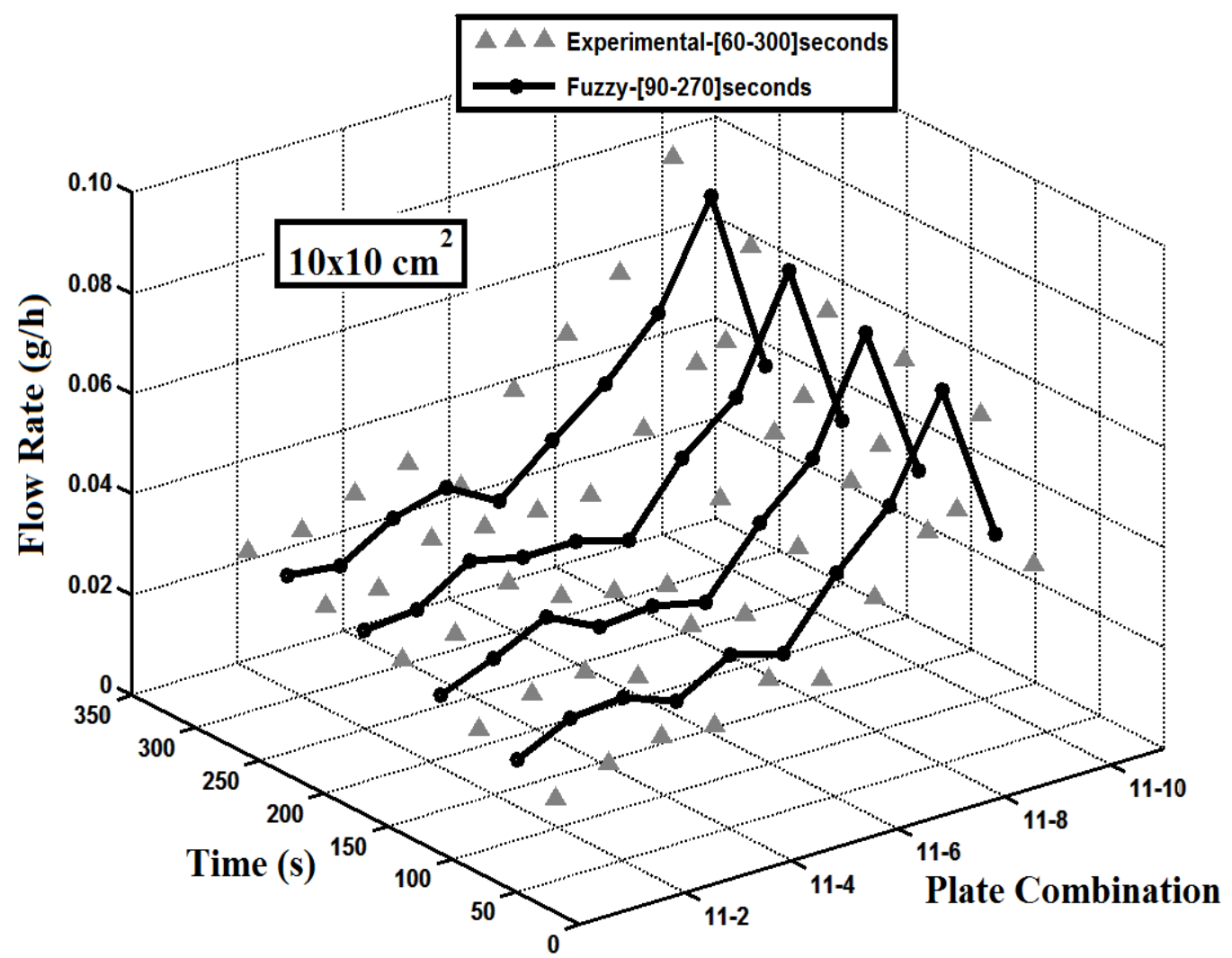

(c)

Figure 3. Comparison of experimental data of $10 \times 10 \mathrm{~cm}^{2}$ plate dimension with fuzzy predict for the variation of time with plate combination of output values (a) Current, (b) Temperature, (c) Flow Rate

These figures present that;

- The current value predicted by RBMTF for the 11-2 plate combination and $t=90 \mathrm{~s}$ is less than the current value from the results of the experimental work for the 11-2 plate combination and $t=60$ $\mathrm{s}$, but higher than the current value from the results of the experimental work for 11-2 plate combination and $t=120$ s (Fig.3a).

- The temperature value predicted by RBMTF for the 11-5 plate combination and $t=210 \mathrm{~s}$ is higher than the temperature value from the results of the experimental work for the 11-5 plate combination and $t=180 \mathrm{~s}$, but less than the temperature value from the results of the experimental work for 11-5 plate combination and $t=240$ s (Fig. 3b).

- The flow rate value predicted by RBMTF for the 11-8 plate combination and $t=270 \mathrm{~s}$ is higher than the flow rate value from the results of the experimental work for the 11-8 plate combination and $t=240 \mathrm{~s}$, but less than the flow rate value from the results of the experimental work for 11-8 plate combination and $t=300$ s (Fig. $3 c$ ). 


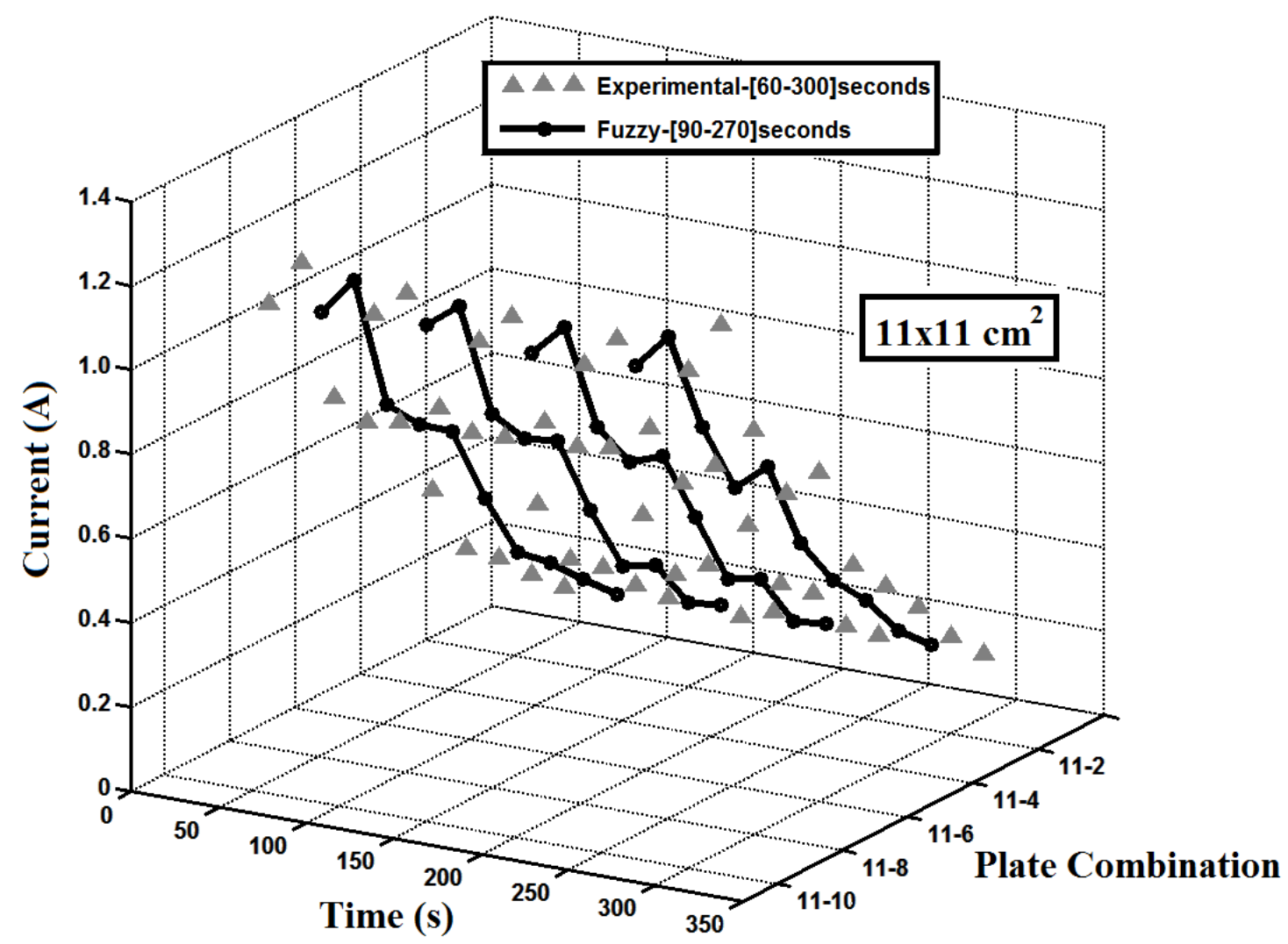

(a)

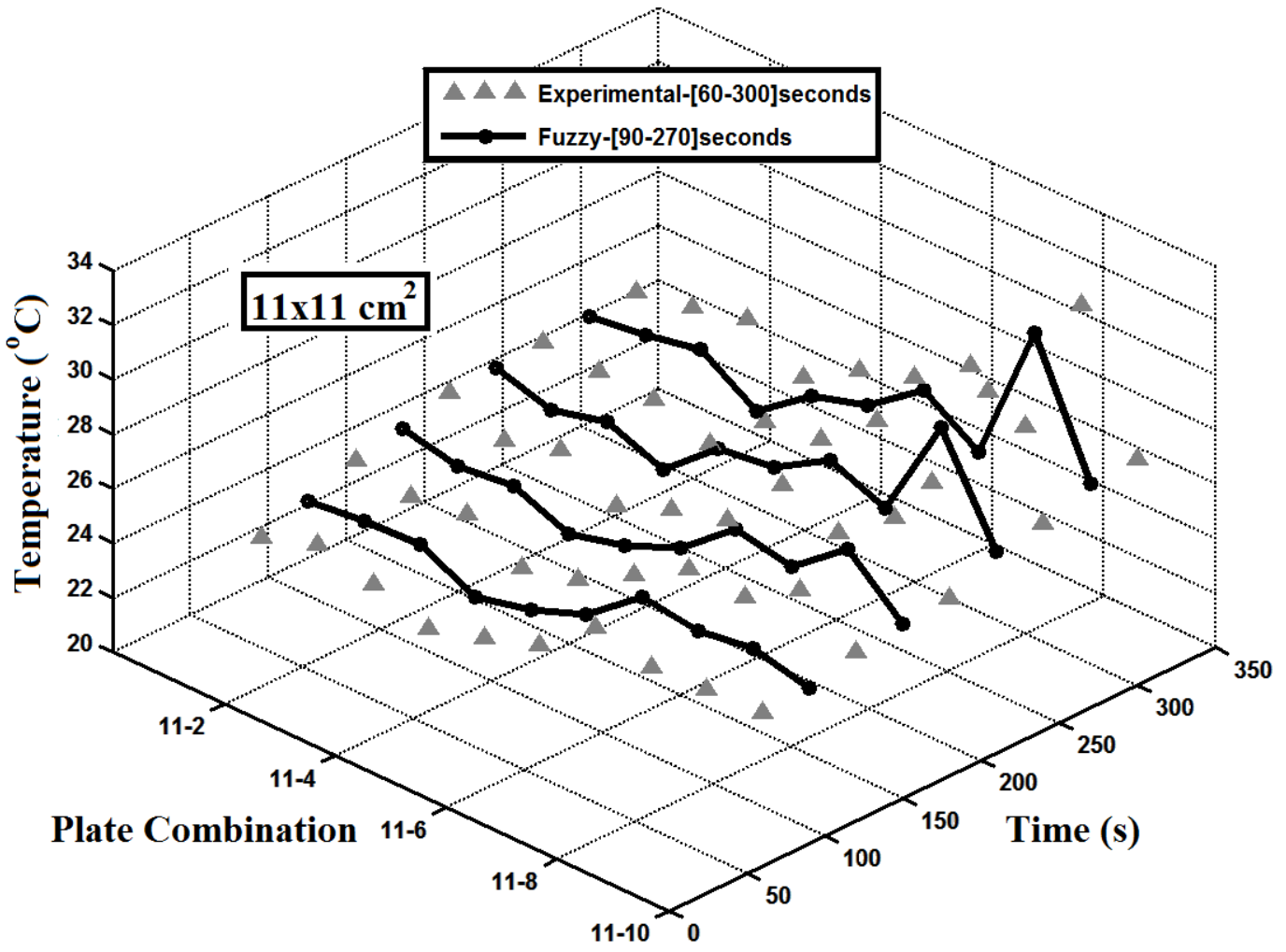

(b) 


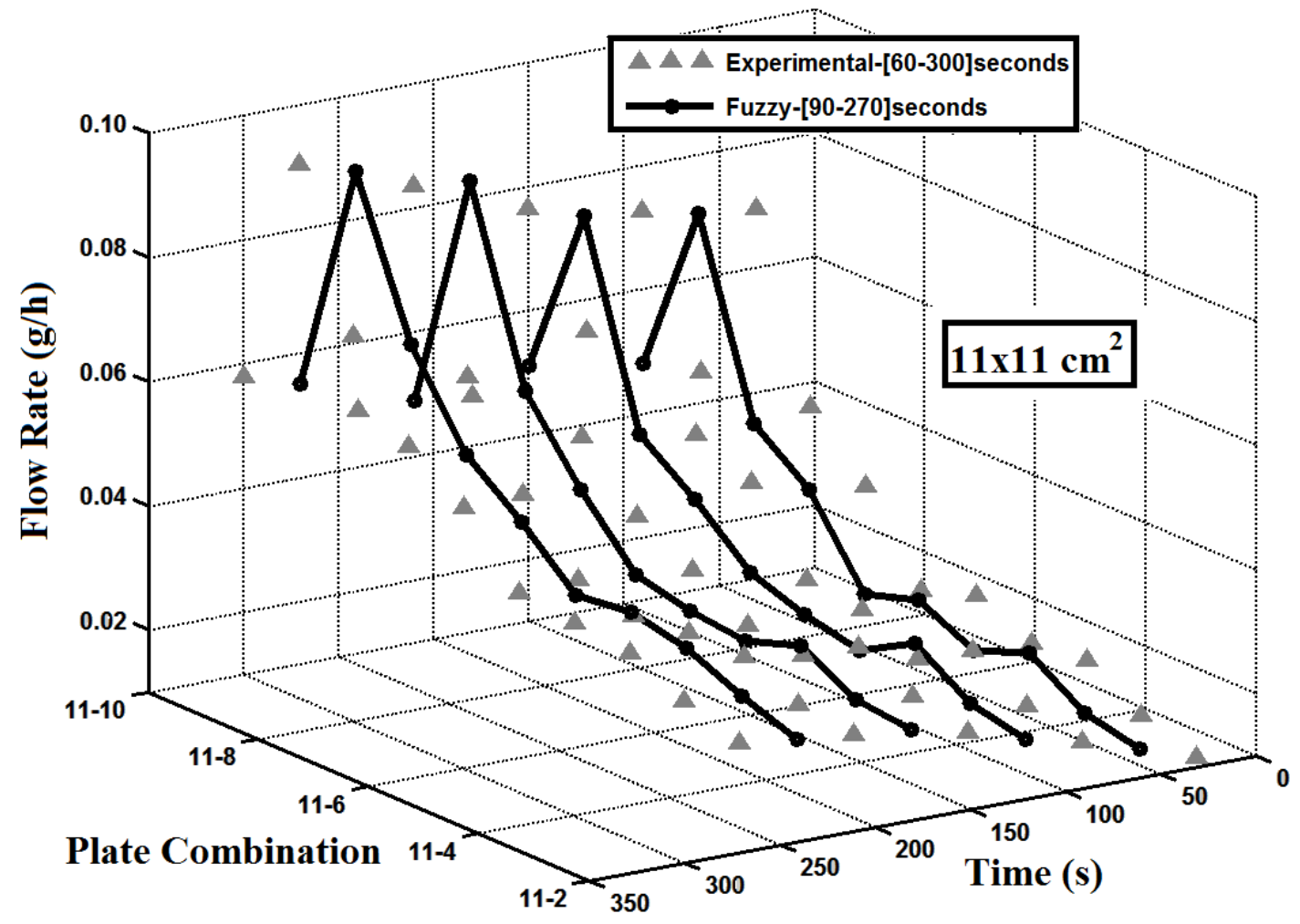

(c)

Figure 4. Comparison of experimental data of $11 \times 11 \mathrm{~cm}^{2}$ plate dimension with fuzzy predict for the variation of time with plate combination of output values (a) Current, (b) Temperature, (c) Flow Rate

Fig. 4 shows respectively, the comparison of experimental data for $11 \times 11 \mathrm{~cm}^{2}$ plate dimensions with fuzzy prediction for the variation of time with plate combination of current, temperature and flow rate values. From a comparison of the experimental results with the results of the fuzzy logic study, one can see that the results are quite compatible.

- The current value predicted by RBMTF for the 11-9 plate combination and $t=150 \mathrm{~s}$ is less than the current value from the results of the experimental work for the 11-9 plate combination and $t=120$ $\mathrm{s}$, but higher than the current value from the results of the experimental work for 11-9 plate combination and $\mathrm{t}=180 \mathrm{~s}$ (Fig. $4 \mathrm{a}$ ).

- The temperature value predicted by RBMTF for the 11-6 plate combination and $\mathrm{t}=210 \mathrm{~s}$ is higher than the temperature value from the results of the experimental work for the 11-6 plate combination and $\mathrm{t}=180 \mathrm{~s}$, but less than the temperature value from the results of the experimental work for 11-6 plate combination and $t=240$ s (Fig. $4 b$ ).

- The flow rate value predicted by RBMTF for the 11-3 plate combination and $t=270 \mathrm{~s}$ is higher than the flow rate value from the results of the experimental work for the 11-3 plate combination and $t=240 \mathrm{~s}$, but less than the flow rate value from the results of the experimental work for 11-3 plate combination and $\mathrm{t}=300 \mathrm{~s}$ (Fig. $4 \mathrm{c}$ ).

The comparison between experimental data and fuzzy logic is done using statistical methods. This methods include; root mean square error (RMSE), mean absolute error (MAE) and the coefficient of multiple determination $\left(R^{2}\right)$. Measures of average error or model performance then are based on statistical summaries of $t_{i}$ (target value) and oi (output value). When Figs. 5-7 and Table 6 are observed, it is found that actual values and the values from fuzzy technique are very close to each other. 


$$
\begin{aligned}
& \mathrm{RMSE}=\sqrt{\frac{1}{N} \sum_{\mathrm{I}=1}^{N}\left(t_{i}-o_{i}\right)^{2}} \\
& \mathrm{MAE}=\frac{1}{N} \sum_{i=1}^{N}\left|t_{i}-o_{i}\right| \\
& R^{2}=1-\left(\frac{\sum_{j}\left(t_{i}-0_{i}\right)^{2}}{\sum_{j}\left(o_{i}\right)^{2}}\right)
\end{aligned}
$$

Fig. $4 \mathrm{a}$ and $\mathrm{b}$ shows comparison of the actual and RBMTF results for $10 \times 10 \mathrm{~cm}^{2}$ and $11 \times 11 \mathrm{~cm}^{2}$ dimension plate current value. For $10 \times 10 \mathrm{~cm}^{2}$ dimension plate, RMSE, MAE and $\mathrm{R}^{2}$ for the current is $0.13,0.111$ and $96.44 \%$ respectively. For $11 \times 11 \mathrm{~cm}^{2}$ dimension plate, RMSE, MAE and $\mathrm{R}^{2}$ for the current is 0.07926 , 0.06466 and $98.44 \%$ respectively.

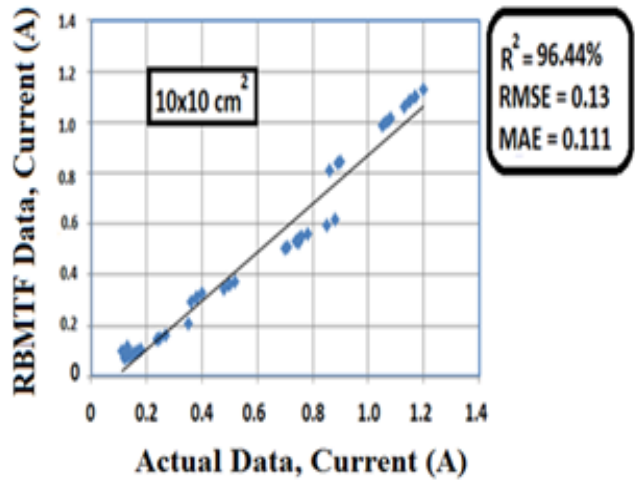

(a)

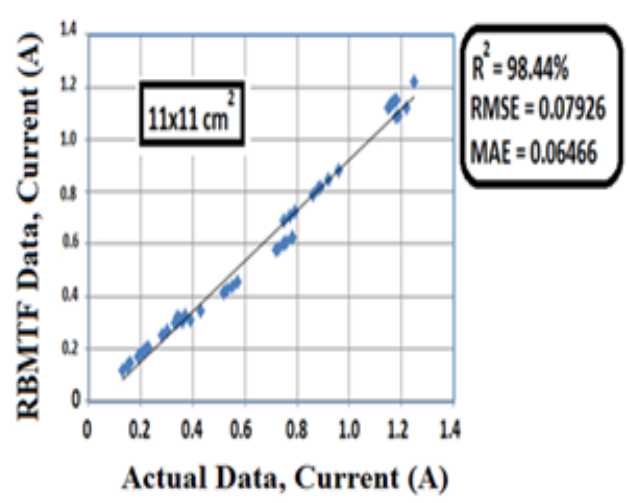

(b)

Figure 5. Comparison of the actual and RBMTF results for current with three different statistical method (a) $10 \times 10 \mathrm{~cm}^{2}$ plate dimension, (b) $11 \times 11 \mathrm{~cm}^{2}$ plate dimension

Fig. $6 a$ and $\mathrm{b}$ shows comparison of the actual and RBMTF results for $10 \times 10 \mathrm{~cm}^{2}$ and $11 \times 11 \mathrm{~cm}^{2}$ dimension plate temperature value. For $10 \times 10 \mathrm{~cm}^{2}$ dimension plate, RMSE, MAE and $\mathrm{R}^{2}$ for the temperature is $0.74406,0.71092$ and $98.97 \%$ respectively. For $11 \times 11 \mathrm{~cm}^{2}$ dimension plate, RMSE, MAE and $\mathrm{R}^{2}$ for the temperature is $0.5082,0.40754$ and $97.56 \%$ respectively.

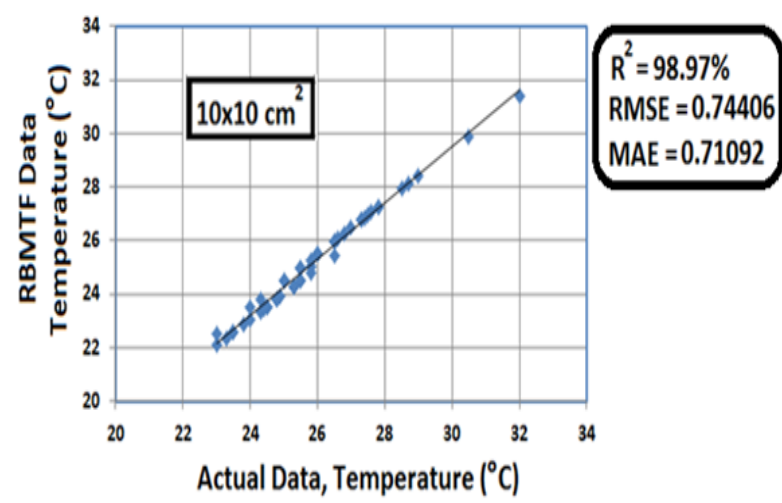

(a)

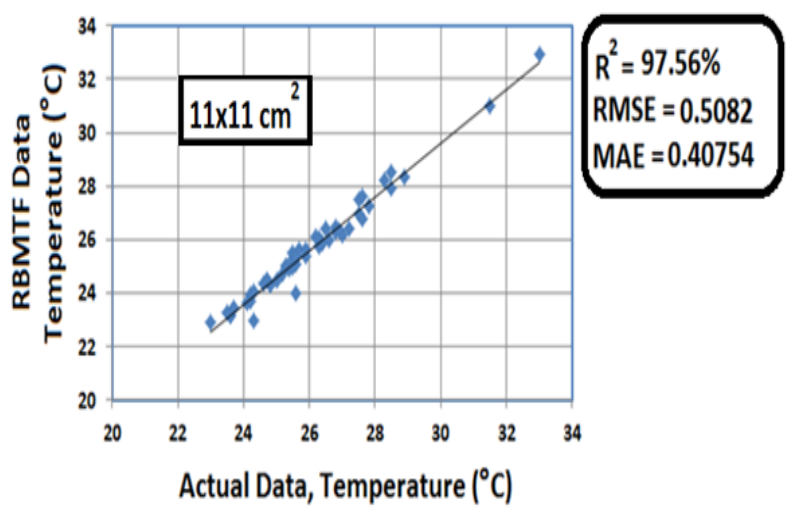

(b)

Figure 6. Comparison of the actual and RBMTF results for temperature with three different statistical method (a) $10 \times 10 \mathrm{~cm}^{2}$ plate dimension, (b) $11 \times 11 \mathrm{~cm}^{2}$ plate dimension 
Fig. 7a and $\mathrm{b}$ shows comparison of the actual and RBMTF results for $10 \times 10 \mathrm{~cm}^{2}$ and $11 \times 11 \mathrm{~cm}^{2}$ dimension plate flow rate value. For $10 \times 10 \mathrm{~cm}^{2}$ dimension plate, RMSE, MAE and $\mathrm{R}^{2}$ for the flow rate is 0.74406 , 0.71092 and $98.97 \%$ respectively. For $11 \times 11 \mathrm{~cm}^{2}$ dimension plate, RMSE, MAE and $\mathrm{R}^{2}$ for the flow rate is $0.5082,0.40754$ and $97.56 \%$ respectively.

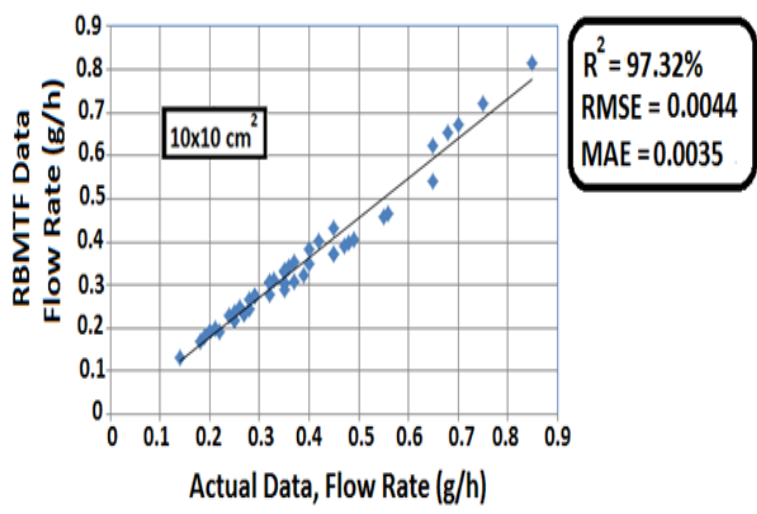

(a)

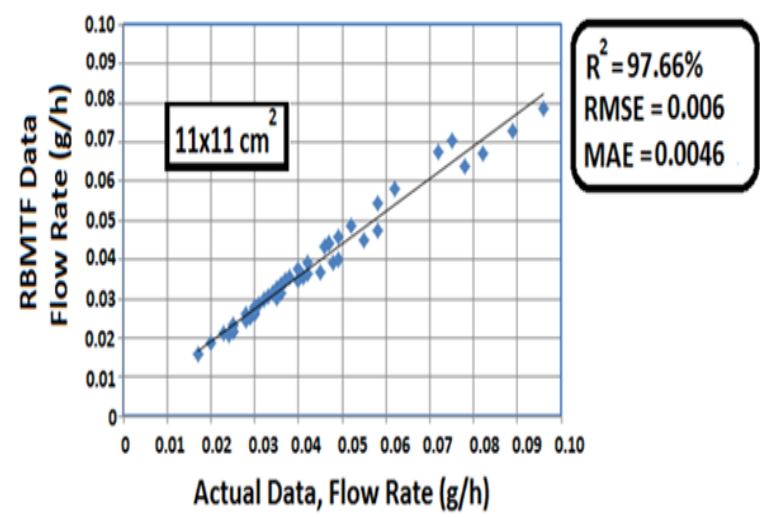

(b)

Figure 7. Comparison of the actual and RBMTF results for current with three different statistical method (a) $10 \times 10 \mathrm{~cm}^{2}$ plate dimension, (b) $11 \times 11 \mathrm{~cm}^{2}$ plate dimension

Table 6. The statistical error values for current $(\mathrm{A})$, temperature $\left({ }^{\circ} \mathrm{C}\right)$, flow rate $(\mathrm{g} / \mathrm{h})$

\begin{tabular}{|l|clll|}
\hline Parameters & $\begin{array}{c}\text { Plate } \\
\text { Dimension }\end{array}$ & RMSE & MAE & $\mathbf{R}^{2}$ \\
\hline Current (A) & $10 \times 10 \mathrm{~cm}^{2}$ & 0.13 & 0.111 & $96.44 \%$ \\
& $11 \times 11 \mathrm{~cm}^{2}$ & 0.07926 & 0.07926 & $98.44 \%$ \\
Temperature ( $\left.{ }^{\circ} \mathbf{C}\right)$ & $10 \times 10 \mathrm{~cm}^{2}$ & 0.74406 & 0.71092 & $98.97 \%$ \\
& $11 \times 11 \mathrm{~cm}^{2}$ & 0.5082 & 0.40754 & $97.56 \%$ \\
Flow Rate $(\mathrm{g} / \mathbf{h})$ & $10 \times 10 \mathrm{~cm}^{2}$ & 0.0044 & 0.0035 & $97.32 \%$ \\
& $11 \times 11 \mathrm{~cm}^{2}$ & 0.006 & 0.0046 & $97.66 \%$ \\
\hline
\end{tabular}

\section{CONCLUSIONS}

Artificial intelligence (AI= fuzzy logic, genetic algorithm, neural network etc.) systems are widely accepted as a technology offering an alternative way to tackle complex and ill-defined problems. They can learn from examples, are fault tolerant in the sense that they are able to handle noisy and incomplete data, they are able to deal with nonlinear problems, and, once trained, they can perform prediction and generalization at high speed. They have been used in diverse applications in control, robotics, pattern recognition, forecasting, medicine, power systems, manufacturing, optimization, signal processing, and social=psychological sciences. They are particularly useful in system modeling, such as in implementing complex mappings and system identification. AI systems comprise areas such as expert systems, artificial neural networks, genetic algorithms, fuzzy logic, and various hybrid systems, which combine two or more techniques (Kalogirou, 2003; Dincer et al., 2008). The aim of this article has been to show the possibility of the use of fuzzy logic for the calculation of performance HHO dry cell with different plate 
combination. Namely, in this study, the method proposed is an alternative to the methods available for HHO dry cell experimental studies.

In the experimental study, tap water was used and the system was set to 5 minutes. For each combination, new cells were prepared. Current, temperature and flow rate values are determined for every 300 values which are obtained on every plate from 60 th second to 600 th second by 60 second intermittently for $10 \times 10 \mathrm{~cm}^{2}$ and $11 \times 11 \mathrm{~cm}^{2}$ plate. HHO dry cell performances in terms of current, temperature and flow rate for 90 th-270th seconds by 60 second intermittently can be predicted by using RBMTF model without attempting any experiments. The temperature value predicted by RBMTF for the 11-6 plate combination and $\mathrm{t}=210 \mathrm{~s}$ is $26.6^{\circ} \mathrm{C}$. This fuzzy predict value higher than the temperature value from the results of the experimental work for the 11-6 plate combination and $t=180 \mathrm{~s}$ is $25.5{ }^{\circ} \mathrm{C}$. The estimated value of fuzzy is less than the temperature value from the results of the experimental work for 11-6 plate combination and $\mathrm{t}=240 \mathrm{~s}$ is $26.8^{\circ} \mathrm{C}$. The comparison between experimental data and fuzzy logic is done using statistical methods. This methods include; root mean square error (RMSE), mean absolute error (MAE) and the coefficient of multiple determination $\left(\mathrm{R}^{2}\right)$. Their results show very acceptable relations between the results of the developed fuzzy model and the experimental results for HHO dry cell performance.

\section{REFERENCES}

Ata, S., 2015, PEM Yakıt Hücresinin Membran Performansının Deneysel Olarak İncelenmesi ve Enerji Ayrışımı Olayının Bulanık Mantık Yöntemi ile Modellenmesi, Yüksek Lisans Tezi, Selçuk Üniversitesi Fen Bilimleri Enstitüsü, Konya.

Ata, S., Dincer, K., "Rule-based Mamdani-type Fuzzy Modeling of Performance Proton Exchange Membrane Fuel Cell With Carbon Nanotube", 15th International Multidisciplinary Scientific GeoConference SGEM 2015, Albena, Bulgaria, pp. 487-494, 18-24 June 2015.

Ata, S., Dincer, K., “Anot Tarafı Karbon Nanotüp İle Kaplanmış PEM Yakıt Hücresi Performansının Bulanık Mantık Yöntemiyle Modellenmesi", Ulusal Hidrojen Teknolojileri Kongresi UHTEK2015, İstanbul, Türkiye, 20-23 Aralık 2015.

Ata, S., Dincer, K., "Improving the Performance of Proton Exchange Membrane Fuel Cell Using Fuzzy Logic", 18th International Conference on Energy and Sustainable Development, Paris, France, pp. 16-17, 16-17 May 2016.

Bölgen, M., 2010, Fuzzy Logic and Data Mining Technıques in Evaluating of Credit Risks of Companies, Master Thesis, Graduate School of Natural and Applied Sciences of Dokuz Eylül University, İzmir.

Chakrapani, K., Neelamegam, P., 2011, “Optimization of Fuel Consumption Using HHO in HDL Technique Verified in FPGA", Journal of Theoretical and Applied Information Technology, Vol. 31, pp. 140-146.

Dincer, K., Ongun, R., Dede, O., 2013, “HHO Hücresinin Performansının Deneysel Olarak Incelenmesi”, Selçuk Üniversitesi Journal of Technical-Online, Vol. 12 (3), ISSN 1302/6178.

Dincer, K., Tasdemir, S., Baskaya, S., Ucgul, I., Uysal, B. Z., 2008, “Fuzzy Modeling of Performance of Counterflow Ranque-Hilsch Vortex Tubes with Different Geometric Constructions", Numerical Heat Transfer, Part B: Fundamentals, Vol. 54 (6), pp. 499-517.

Esteves, R.M., 2009, Data Fusion Algorithms for Assessing Sensors Accuracy in an Oil Production Well A Bayesian approach, MSc Thesis, University of Stavanger Faculty of Science and Technology.

Işıktaş, A., Dincer, K., Ata, S., "Comparison Between the Effects of Different Types of Membership Functions on Fuzzy Logic for Hydroxy Dry Cell Performance", 16th International Multidisciplinary Scientific GeoConference SGEM 2016, Albena, Bulgaria, 28th June - 7th July 2016.

Kalogirou, S.A., 2003, "Artificial Intelligence for the Modeling and Control of Combustion Processes: A Review", Progress in Energy and Combustion Science, Vol. 29, pp. 515-566. 
Keshwani, D.R., Jones, D. D., Meyer, G.E.R, Brand, M., 2008, “Rule-based Mamdani-type Fuzzy Modeling of Skin Permeability", Applied Soft Computing, Vol. 8, pp. 285-294.

Kim, Y., Kim, S., 1999, "An Electrical Modelling and Fuzzy Logic Control of a Fuel Cell Generation System", IEEE Transactions on Energy Conversion, Vol. 14, pp. 239-244.

Leelakrishnan, E., Lokesh, N., Suriyan, H., 2013, "Performance and Emission Characteristics of Brown's Gas Enriched Air in Spark Ignition Engine", International Journal of Innovative Research in Science, Engineering and Technology, Vol. 2, pp. 393-404.

Madyira, D., Harding, W., "Effect of HHO on Four Stroke Petrol Engine Performance", 9th South African Conference on Computational and Applied Mechanics, 14-16 Jan 2014.

Özek, A., Sinecen, M., 2004, "Klima Sistem Kontrolünün Bulanık Mantık ile Modellemesi”, Pamukkale Üniversitesi Mühendislik Bilimleri Dergisi, Vol. 10, pp. 353-358.

Sakthıvel, S., 2014, “An Experimental Assessment of Performance and Exhaust Emission Characteristics by Addition of Hydroxy (HHO) Gas in Twin Cylinder C.I. Engine", International Journal of Innovative Research in Science, Engineering and Technology, Vol. 3(2), pp. 60-65.

Shakhawat, C., Tahir, H., Neil, B., 2006, "Fuzzy Rule-Based Modelling for Human Health Risk from Naturally Occurring Radioactive Materials in Produced Water", Journal of Environmental Radioactivity, Vol. 89, pp. 1-17.

Tiryaki, A.E., Kazan, R., 2007, "Bulaşık Makinesinin Bulanık Mantık ile Modellenmesi”, Mühendis ve Makine, Vol. 48, pp. 3-8.

Tong, S.W., Qian, D.W., Fang, J.J., Li, H.X., 2013, "Integrated Modelling and Variable Universe Fuzzy Control of a Hydrogen-Air Fuel Cell System", International Journal of Electrochemical Science, Vol. 8(3), pp. 3636-3652.

Yıldız, Ş., Kişoğlu, S., 2011, "Bulanık Mantık Yaklaşımı ile Hazır Giyimde Beden Numarası Belirleme”, E-Journal of New World Sciences Academy, Vol. 6, pp. 12-22. 